\title{
Discovery of Novel Antitumor Dibenzocyclooctatetraene Derivatives and Related Biphenyls as Potent Inhibitors of NF-kB Signaling Pathway
}

\author{
Fang-Lin $\mathrm{Yu}^{\mathrm{a}}, \|$, Xiao-Yang He $\mathrm{He}^{\mathrm{a}, \mathrm{d}, \|}$, Chunping $\mathrm{Gu}^{\mathrm{b}}$, Emika Ohkoshi ${ }^{\mathrm{c}}$, Li-Ting Wang ${ }^{\mathrm{c}}$, Sheng- \\ Biao Wang ${ }^{a}$, Chin-Yu Lai ${ }^{c}$, Le Yu ${ }^{b}$, Susan L. Morris-Natschke ${ }^{c}$, Kuo-Hsiung Lee ${ }^{\mathrm{c}, e}$, Shuwen \\ Liu $^{\mathrm{b}}$, and Lan Xie ${ }^{\mathrm{a},{ }^{*}}$ \\ aBeijing Institute of Pharmacology and Toxicology, Beijing 100850, China \\ bSchool of Pharmaceutical Sciences, Southern Medial University, Guangzhou 510515, China \\ 'Natural Products Research Laboratories, UNC Eshelman School of Pharmacy, University of \\ North Carolina, Chapel Hill, NC27599, USA \\ dBeijing Institute of Radiation Medicine, Beijing 100850, China \\ eChinese Medicine Research and Development Center, China Medical University and Hospital, \\ Taichung Taiwan
}

\begin{abstract}
Several dibenzocyclooctatetraene derivatives (5-7) and related biphenyls (8-11) were designed, synthesized, and evaluated for inhibition of cancer cell growth and the NF- $\kappa \mathrm{B}$ signaling pathway. Compound 5a, a dibenzocyclooctatetraene succinimide, was discovered as a potent inhibitor of the $\mathrm{NF}-\kappa \mathrm{B}$ signaling pathway with significant antitumor activity against several human tumor cell lines $\left(\mathrm{GI}_{50} 1.38-1.45 \mu \mathrm{M}\right)$ and was more potent than paclitaxel against the drug-resistant KBvin cell line. Compound 5a also inhibited LPS-induced NF- $\kappa$ B activation in RAW264.7 cells with an $\mathrm{IC}_{50}$ value of $0.52 \mu \mathrm{M}$, prevented I $\mathrm{B}$ - $\alpha$ degradation and $\mathrm{p} 65$ nuclear translocation, and suppressed LPS-induced NO production in a dose-dependent manner. The antitumor data in cellular assays indicated that relative positions and types of substituents on the dibenzocyclooctatetraene or acyclic biphenyl as well as torsional angles between the two phenyls are of primary importance to antitumor activity.
\end{abstract}

\section{Keywords}

dibenzocyclooctatetraene derivatives; unsymmetrical biphenyls; anticancer agents; NF- $\kappa \mathrm{B}$ inhibitor

\footnotetext{
(C) 2013 Elsevier Ltd. All rights reserved.

*Corresponding author. Xie L, Tel: 86-10-6931690, Fax: 86-10-66931690, lanxieshi@yahoo.com; Liu S, Tel: 86-20-61648538, Fax: 86-20-61648655, liusw@smu.edu.cn; Lee, K.H., Tel: 919-962-0066, Fax: 919-966-3893, khlee@unc.edu.

These authors contributed equally to this work.

Supplementary Data. HPLC purity and conditions for active compounds $\mathbf{5 a - 5 c , ~ 8 b - 8 g , ~ 9 a , ~ 9 d , ~ 1 0 a - 1 0 c , ~ 1 1 a , ~ 1 1 b . ~}$

Publisher's Disclaimer: This is a PDF file of an unedited manuscript that has been accepted for publication. As a service to our customers we are providing this early version of the manuscript. The manuscript will undergo copyediting, typesetting, and review of the resulting proof before it is published in its final citable form. Please note that during the production process errors may be discovered which could affect the content, and all legal disclaimers that apply to the journal pertain.
} 


\section{Instruction}

Despite many technological advances during the past two decades, natural products remain one of the most important sources of novel leads for new drugs. Dibenzocyclooctadiene lignans are major constituents of the traditional Chinese medicinal plant Schizandra chinensis, and show diverse biological activities, ${ }^{1,2}$ including antiviral, hepatoprotective, anticancer, and anti-inflammatory effects. Various synthetic studies on natural dibenzocyclooctadiene lignans were reported during the $1970 \mathrm{~s}, 3,4$ and recently, interest in this area has revived. ${ }^{5,6,7}$ During our prior attempts to synthesize the natural product gomisin $\mathrm{G},{ }^{8}$ we produced and evaluated a series of unsymmetrical biphenyls for cytotoxicity against several human cancer cell lines, resulting in the discovery of a new lead compound, 1 (Figure 1). ${ }^{9}$ Compound 1 showed promising cytotoxicity against human A549 (lung), DU145 (prostate), KB (nasopharyngeal), and drug-resistant KBvin cancer cell lines with low $\mathrm{GI}_{50}$ values of $0.12,0.29,0.41$ and $0.51 \mu \mathrm{M}$, respectively. Notably, lead 1 displayed similar potencies against KB and paclitaxel-resistant KBvin cell lines, while the anticancer drug paclitaxel exhibited significantly reduced potency against KBvin compared with KB cells (GI ${ }_{50} 1800$ and $8 \mathrm{nM}$, respectively). In a continuing study to explore novel antitumor agents, gomisin $\mathrm{G}$ analogs (5-7) with a dibenzocyclooctatetraene skeleton were synthesized from unsymmetrical 2,2'-diformylbiphenyls. Meanwhile, new biphenyls (8-11) based on lead 1 were also obtained from formylbiphenyl intermediates. Structurally, the biphenyl compounds are analogous to dibenzocyclooctatetraenes lacking a C6-C7 bond to form the cyclooctatetranene ring. Various $2,2^{\prime}$-substituents $\left(\mathrm{R}_{1}\right.$ and $\left.\mathrm{R}_{2}\right)$ with a conjugated doublebond were introduced and the biphenyl A- and B-tings were modified with different patterns of methoxy and methylenedioxy groups, which are commonly found in natural products. Steric compression between the two bulky $2,2^{\prime}$-groups could affect torsion angles between the two phenyl rings of the biphenyl series, which could in turn affect the biological activity. Thus, we were interested in whether correlations would be found between activities of the two series, acyclic biphenyls and dibenzocyclooctatetraenes. To evaluate antitumor activity, newly synthesized compounds were initially evaluated in human tumor cell lines (HTCL) assays, and active compounds were then tested for inhibition of the nuclear factor kappa B $(\mathrm{NF}-\kappa \mathrm{B})$ signaling pathway, as aberrant NF- $\kappa \mathrm{B}$ regulation is observed in various hematological malignancies and solid tumors. ${ }^{10,11}$ Continuing activation of NF- $\kappa B$ in tumor cells turns on expression of genes that maintain cell proliferation and protect the cell from death via apoptosis. Thus, blocking NF- $\kappa B$ and its signaling pathway can cause tumor cells to stop proliferating, to die, or to be more sensitive to the action of antitumor agents, providing promising target(s) and approaches for anticancer therapy. ${ }^{12}$ Herein, we report the synthesis of dibenzocyclooctatetraene derivatives and related biphenyl compounds, their antitumor activity against a HTCL panel, inhibitory activity against the NF- $\kappa B$ signaling pathway, SAR analysis, and results on mechanism studies using the most active compound $5 \mathbf{a}$ as a probe.

\section{Chemistry}

Chemical syntheses of the two series of target compounds are described in Schemes 1 and 2, respectively. The key intermediate unsymmetrical mono- and di-formylbiphenyls (4) were synthesized by a Suzuki cross-coupling reaction between a phenylboronic acid (2) and a bromobenzene (3). As shown in Scheme 1, 6-formyl-2,3,4-trimethoxyphenylboronic acid (2a) was coupled individually with 2-bromopiperonal (3a), 2-bromoveratraldehyde (3b), or 2-bromobenzaldehyde (3c) using $\mathrm{Pd}(\mathrm{dppf}) \mathrm{Cl}_{2}(5 \% \mathrm{~mol})$ as catalyst in the presence of anhydrous $\mathrm{Cs}_{2} \mathrm{CO}_{3}$ to produce 2,2'-diformylbiphenyls 4a-c, respectively. Subsequently, 4a-c were reacted with a stable phosphorane Wittig reagent formed by $\mathrm{Bu}_{3} \mathrm{P}$ and maleimide, ${ }^{13}$ followed by an intramolecular Knoevenagel condensation to afford dibenzocyclooctatetraene succinimides 5a-c, respectively. In a similar manner, 
dibenzocyclooctatetraene compounds $\mathbf{6 a}$ and $\mathbf{6} \mathbf{b}$ were prepared by Wittig reaction of dimethyl maleate and $\mathrm{Bu}_{3} \mathrm{P}$ with diformylbiphenyl $\mathbf{4 a}$ and $\mathbf{4 b}$, respectively, and a subsequent intramolecular cyclization via Knoevenagel condensation in the presence of piperidine and $\mathrm{HOAc}$ in benzene under microwave irradiation. Wittig reagents prepared using $\mathrm{Bu}_{3} \mathrm{P}$ are easily purified, because a water-soluble phosphine oxide $\mathrm{Bu}_{3} \mathrm{P}=\mathrm{O}$ is produced. Succinimide compound 5a was further hydrolyzed under basic conditions to afford 6,7-dicarboxylic dibenzocyclooctatetraene analog 7 . Syntheses of unsymmetrical biphenyls with bulky $2,2^{\prime}-$ conjugated substituents (8-11) are shown in Scheme 2. A Suzuki cross-coupling reaction was used to prepare formylbiphenyl intermediates $\mathbf{4 d - f}$ from commercially available 2formylphenylboronic acid (2b) with methyl 2-bromo-3,4,5- trimethoxybenzoate (3d), 2bromo-3-methoxy-4,5-methylenedioxybenzaldehyde (3e), or 2-bromo-3,4methylenedioxy-5-methoxybenzaldehyde (3f), respectively. Next, Knoevenagel condensation of formylbiphenyls 4a-f with nitroethane, nitromethane, ethyl cyanoacetate, or malononitrile, respectively, yielded corresponding unsymmetrical biphenyls 8-11 with 2and/or 2'-substituents containing a conjugated double bond. Series 8 compounds have no other substituents on the phenyl B-ring, while series 9 and $\mathbf{1 0}$ have a methylenedioxy (9a-d) or two methoxy groups (10a-c) at the $4^{\prime}$ - and 5'-positions on the B-ring, respectively. In addition, modifications on the A-ring of 1 produced a pair of isomers 11a and 11b, in which a methylenedioxy plus a methoxy group replaced the original three methoxy groups on the phenyl A-ring. All new compounds were identified by mass and nuclear magnetic resonance spectra.

\section{Results and Discussion}

According to procedures described previously, ${ }^{14,15}$ the newly synthesized dibenzocyclooctadienes (5-7) and unsymmetrical biphenyl compounds (8-11) were tested against a HTCL panel, including A549, DU145, KB, and KBvin cell lines, with paclitaxel as the positive control. In vitro anticancer activity $\left(\mathrm{GI}_{50}\right)$ was determined using the established SRB (sulforhodamine B) method. ${ }^{16}$ To explore the possible biological target and mechanism of action, active compounds were screened initially at $10 \mu \mathrm{M}$ in RAW264.7 cells to evaluate NF- $\kappa B$ inhibitory activity. Compounds that showed greater than $98 \%$ inhibition at this concentration were further evaluated at serial concentrations to obtain corresponding $\mathrm{IC}_{50}$ values in parallel with positive control BAY 11-7086. Related data of the two compound series are shown in Tables 1 and 2. Interestingly, dibenzocyclooctatetraene succinimide compounds 5a-c showed promising inhibitory activity in the above assays. The most potent compound 5a exhibited low $\mathrm{GI}_{50}$ values $(1.38-1.47 \mu \mathrm{M})$ against cancer cell proliferation in the tested HTCL panel and a submicromolar $\mathrm{IC}_{50}$ value of $0.52 \mu \mathrm{M}$ in the NF- $\kappa \mathrm{B}$ signaling pathway assay. However, when the succinimide ring was opened, dibenzocyclooctatetraene 6,7-dicarboethoxy compounds $\mathbf{6 a}, \mathbf{6 b}$, or 6,7-dicarboxylate compound 7 were at least 10fold less potent in comparison with $\mathbf{5 a}$, suggesting that the succinimide moiety might be important for antitumor activity. In addition, comparison of $\mathbf{5 a}$ with $\mathbf{5 b}$ and $\mathbf{6 a}$ with $\mathbf{6 b}$ indicate that a methylenedioxy on the phenyl ring (B-ring) is more favorable than two methoxy groups at the same positions.

The new series of unsymmetrical biphenyls extended our prior studies and provided more SAR information. The series $\mathbf{8}$ compounds were designed to have the same biphenyl scaffold as lead $\mathbf{1}$, but different $2,2^{\prime}$-substituents, including nitrovinyl, cyanovinyl, and ester groups. Compound $\mathbf{8 d}$ with 2,2'-dinitrovinyl substitution showed potent antitumor activity with $\mathrm{GI}_{50}$ values ranging from 2.09 to $4.60 \mu \mathrm{M}$ in the HTCL panel, but was less potent than 1. Compounds $8 \mathbf{e}$ with a 2-carbomethoxy and a $2^{\prime}$-(2-methyl-2- nitro)vinyl group and $\mathbf{8 b}$ with 2,2'-di-(2-carboethoxy-2-cyano)vinyl groups exhibited moderate potency with low micromolar $\mathrm{GI}_{50}$ values ranging from 6.17 to $6.95 \mu \mathrm{M}$ and 6.53 to $8.45 \mu \mathrm{M}$, respectively but 
were less potent than $\mathbf{8 d}$. In contrast, $8 \mathbf{c c}, \mathbf{8 f}$, and $8 \mathbf{g}$ without a nitrovinyl group at the $2,2^{\prime}$ position were inactive $\left(\mathrm{GI}_{50}>20 \mu \mathrm{M}\right)$.

The same potency pattern was observed in series 9 and $\mathbf{1 0}$ biphenyls, which contain a $4^{\prime}, 5^{\prime}$ methylenedioxy or $4^{\prime}, 5^{\prime}$-dimethoxy substitution, respectively, on the phenyl B-ring. As expected, compound 9a with 2,2'-di-(2-methyl-2-nitro)vinyl groups showed low micromolar $\mathrm{GI}_{50}$ values ranging from 0.72 to $1.51 \mu \mathrm{M}$ in the cellular assays, which were similar to those of lead $\mathbf{1}$ and 5a. Compound 9a was more potent than 2,2'-dinitrovinyl 9d $\left(\mathrm{GI}_{50}\right.$ 5.49-9.09 $\mu \mathrm{M})$, di-2-carboethoxy-2-cyanovinyl $\mathbf{9 b}\left(\mathrm{GI}_{50}>22 \mu \mathrm{M}\right)$, and 2,2'-dicyanovinyl $9 \mathbf{c}\left(\mathrm{GI}_{50}>40\right.$ $\mu \mathrm{M})$. Similarly, 10a was also more potent than $\mathbf{1 0 b}$ and $\mathbf{1 0 c}$.

Di-(2-methyl-2-nitro)vinyl biphenyls 11a and 11b each have with one methylenedioxy (positions 4/5 in 11a and 5/6 in 11b) and one methoxy group (position 6 in 11a and 4 in 11b) on the A-ring, rather than the three methoxy groups found in lead 1. Neither compound was more potent than $\mathbf{1}$ in the antitumor cellular assays. However, compound 11a displayed selective potency against A549 and DU145 cell proliferation $\left(\mathrm{GI}_{50} 4.02\right.$ and $5.02 \mu \mathrm{M}$ respectively) compared with $\mathrm{KB}$ and $\mathrm{KBvin}\left(\mathrm{GI}_{50} 13.6\right.$ and $\left.12.31 \mu \mathrm{M}\right)$, while $11 \mathrm{~b}$ was less potent against all four cell lines $\left(\mathrm{GI}_{50} 13.89-19.82 \mu \mathrm{M}\right)$.

In summary, the cellular assay results on the biphenyls indicated that (1) $2,2^{\prime}$-substituents significantly affect antitumor potency regardless of other substituents on the biphenyl ring system, (2) conjugated nitrovinyl substituents at the $2,2^{\prime}$-positions are more favorable than other substituents on these positions, which is consistent with prior literature, ${ }^{17}$ and (3) trimethoxy substitution on the biphenyl A-ring is preferred compared with both methoxy and methylenedioxy groups at different positions based on a limited data set.

Active dibenzocyclooctatetraene (5a-c) and nitrovinylbiphenyls (1, 8d, 8e, 9a, 9d, 10a, 11a and 11b) were further assayed for inhibitory effects on the NF- $\kappa B$ signaling pathway in RAW264.7 cells, which are stably transfected with a luciferase reporter gene controlled by NF- $\kappa$ B activation. ${ }^{18}$ Interestingly, the compounds exhibited promising inhibitory activity in this assay with $\mathrm{IC}_{50}$ values ranging from 0.52 to $2.16 \mu \mathrm{M}$. The inhibitory potency was comparable or greater than that of positive control BAY 11-7086 ( IC $\left._{50} 1.72 \mu \mathrm{M}\right)$, a pharmacological inhibitor of $\mathrm{I} \kappa \mathrm{B}$ kinase, indicating that these active compounds do interfere with the NF- $\kappa B$ signaling pathway. Consequently, dibenzocyclooctatetraene succinimide $\mathbf{5 a}$ was tested in parallel with positive control BAY 11-7082 in further assays based on the NF$\kappa \mathrm{B}$ signaling pathway. Firstly, we found that $\mathbf{5 a}$ indeed suppressed lipopolysaccharide (LPS)-induced NF- $\kappa$ B activation dose-dependently As shown in Fig 2, RAW264.7 cells, stably expressing the NF- $\kappa \mathrm{B}$ luciferase reporter gene, were stimulated with LPS to increase luciferase activity in the presence or absence of $\mathbf{5 a}$ before measurement of luciferase activity. The cells treated with $10 \mu \mathrm{M}$ of $\mathbf{5 a}$ completely inhibited LPS-induced NF- $\kappa \mathrm{B}$ activation comparable to BAY11-7082 at $20 \mu \mathrm{M}$. Next, the underlying mechanisms of action of $\mathbf{5 a}$ were investigated. As a pharmacological inhibitor of the actions of I $\mathrm{KB}$ kinase, BAY 11-7082 can prevent the translocation of free NF- $\kappa B$ to the nucleus and, thus, was used as a reference in Western blotting to confirm the action of 5a. As shown in Fig. 3, the p65 subunit of NF- $\kappa \mathrm{B}$, a major component in NF- $\kappa \mathrm{B}$ complex activation, was translocated into the nucleus after LPS challenge. However, pretreatment with 5a substantially inhibited translocation of $\mathrm{p} 65$ in a dose-dependent manner. Since I $\mathrm{KB}$ protein degradation is an essential step for NF- $\kappa$ B activation induced by LPS, Figure 3 also illustrates that LPS stimulation induced a marked degradation of $\mathrm{I} \kappa \mathrm{B}$, while this degradation was suppressed by 5a in a dose-dependent manner. On the other hand, nitric oxide (NO) is known to function as a pro-inflammatory mediator in the pathogenesis of inflammation. Overproduction of NO may have detrimental consequences and seems to be involved in the pathophysiology of various human diseases. As shown in Fig 4, RAW264.7 cells without LPS stimulation 
produced minimal NO in the supernatant, while cells released significantly higher levels of NO in response to LPS exposure. When RAW264.7 cells were treated with 5a, the elevation of NO release was significantly reduced relative to the dose. The reduction in LPS-induced NO production to $\mathbf{5 a}$ at a concentration of $2.5 \mu \mathrm{M}$ was comparable with the decrease in response to a higher concentration $(20 \mu \mathrm{M})$ of BAY 11-7082. Based on the results, we suggest that 5a is a more effective NO inhibitor than BAY 11-7082.

Because molecular binding orientation is related to biological activity, we wanted to observe changes in the biphenyl torsion angle, $\mathrm{C} 2-\mathrm{C} 1-\mathrm{C} 1^{\prime}-\mathrm{C} 6{ }^{\prime}$ (Fig 5), as well as determine possible relationships between dibenzocyclooctatetraenes and acyclic biphenyls. Therefore, even though the actual biological target(s) has not been identified, we performed conformational searches on the two compound series using Discovery Studio 3.0. For the minimized conformers of dibenzocyclooctatetraenes, the biphenyl torsion angles of $\mathrm{C} 2-\mathrm{C} 1-\mathrm{Cl}^{\prime}-\mathrm{C}^{\prime}$ ranged from $110^{\circ}$ to $130^{\circ}$ (defined as in Fig 5), irrespective to whe ther the compound was active or inactive. For example, active compound 5a shows a torsional angle of $129.8^{\circ}$ and inactive $\mathbf{6 b}$ has a $114.1^{\circ}$ angle. Considering the steric compression of the $2,2^{\prime}$-bulky groups, we postulated that the $\mathrm{C} 2-\mathrm{C} 1-\mathrm{C}^{\prime}-\mathrm{C}^{\prime}$ torsional angle in the acyclic biphenyls would deviate from those of related dibenzocyclooctatetraenes. Interestingly, we found that active dinitrovinylbiphenyl 9a displayed a torsional angle of $122.2^{\circ}$ similar to that of active 5a, while the torsional angle of inactive $2,2^{\prime}$-dicyanovinyl biphenyl $9 \mathbf{c}\left(101.4^{\circ}\right)$ did not fall in the above range. The conformers of representative compounds are shown in Figure 5. We suggest that the torsional angle between the two phenyl rings, either in dibenzocyclooctatetraenes or biphenyls, may impact the molecular antitumor activity because molecular binding orientations can affect interactions between small molecules and their biological target.

\section{Conclusions}

This study discovered new dibenzocyclooctatetraene succinimides (5a-c) and related unsymmetric 2- and/or 2'-nitrovinyl biphenyls $(\mathbf{8 b}, \mathbf{8 d}-\mathbf{e}, 9 \mathbf{9 a}, 9 \mathbf{d}, \mathbf{1 0 a}, \mathbf{1 1 a})$ with promising cytotoxic $\left(\mathrm{GI}_{50}<10 \mu \mathrm{M}\right.$ in a HTCL panel) and NF- $\kappa \mathrm{B}$ inhibitory ( $\mathrm{IC}_{50}$ values $0.52-3.02$ $\mu \mathrm{M})$ activities. The results suggest that these antitumor agents are potential NF- $\kappa \mathrm{B}$ signaling pathway inhibitors. In mechanism of action studies based on NF- $\kappa \mathrm{B}$ signaling pathway assays, the most potent compound 5a suppressed lipopolysaccharide (LPS)-induced NF- $\kappa B$ activation in RAW264.7 cells ( $\mathrm{IC}_{50} 0.52 \mu \mathrm{M}$ ), inhibited LPS-induced degradation of $\mathrm{I} \kappa \mathrm{Ba}$ and nuclear translocation of p65, and significantly blocked LPS-induced nitric oxide (NO) production at low concentrations $(0.6-2.5 \mu \mathrm{M})$. The results demonstrated that $\mathbf{5 a}$ has an inhibitory profile similar to that of IKK inhibitor BAY 11-7082, implying 5a may reduce LPS-induced NF- $\kappa B$ activation via inhibition of IKK activities. The antitumor data in cellular assays indicated that the relative positions and types of substituents either on the dibenzocyclooctatetraene or the acyclic biphenyl as well as the torsional angles between the two phenyls are of primary importance to antitumor activity.

\section{Experimental Section}

\subsection{Chemistry}

Melting points were measured with a RY-1 melting apparatus without correction. The proton nuclear magnetic resonance $\left({ }^{1} \mathrm{H}\right.$ NMR) spectra were measured on a JNM-ECA-400 (400 MHz) spectrometer using tetramethylsilane (TMS) as internal standard. The solvent used was $\mathrm{CDCl}_{3}$ unless indicated. Mass spectra (MS) were measured on API-150EX mass spectrometer with electrospray ionization connected with an Agilent 1100 system. Thinlayer chromatography (TLC) was performed on silica gel $\mathrm{GF}_{254}$ plates. Silica gel GF254 and H (200-300 mesh) from Qingdao Haiyang Chemical Company was used for TLC, 
preparative TLC, and column chromatography respectively. Medium-pressure column chromatography was performed using a CombiFlash ${ }^{\circledR}$ companion system from ISCO, Inc. to purify target compounds. All chemicals were obtained from Beijing Chemical Works or Sigma-Aldrich, Inc.

\subsubsection{General process of Suzuki cross-coupling to prepare mono- or di- formylbiphenyls (4a-f)_A mixture of a substituted bromobenzene (1 equiv) and a phenylboronic acid (1.5 equiv) in the presence of $\mathrm{Pd}(\mathrm{dppf}) \mathrm{Cl}_{2}(5 \% \mathrm{~mol})$ and $\mathrm{Cs}_{2} \mathrm{CO}_{3}(2.0$ equiv) in 1,2-dimethoxyethane (DME, ca $10 \mathrm{~mL}$ ) was heated to $80^{\circ} \mathrm{C}$ for $8-12 \mathrm{~h}$ under $\mathrm{N}_{2}$ protection. After cooling to room temperature, the mixture was diluted with EtOAc and filtered through celite. The filtrate was washed with water and brine, successively, and dried over $\mathrm{Na}_{2} \mathrm{SO}_{4}$. After removal of solvent in vacuo, the residue was purified by a flash column (gradual elution: EtOAc/petroleum ether $0 \sim 40 \%$ ) to afford corresponding formylbiphenyls.}

5.1.1.1 2,2' -Diformyl-4',5'-methylenedioxy-4,5,6-trimethoxybiphenyl (4a): Starting with 2-bromopiperonal (3a, $300 \mathrm{mg}, 1.31 \mathrm{mmol}$ ) and 6-formyl-2,3,4-trimethoxyphenyl boronic acid (2a, $470 \mathrm{mg}, 1.96 \mathrm{mmol}$ ) to afford $210 \mathrm{mg}$ of $\mathbf{4 a}, 47 \%$ yield, white solid, 138-140 ${ }^{\circ} \mathrm{C} ;{ }^{1} \mathrm{H}$ NMR $\delta$ ppm $9.64 \& 9.58$ (each $\left.1 \mathrm{H}, \mathrm{s}, \mathrm{CHO}\right), 7.51\left(1 \mathrm{H}, \mathrm{s}, \mathrm{ArH}-3^{\prime}\right), 7.38(1 \mathrm{H}, \mathrm{s}$, ArH-3), $6.74\left(1 \mathrm{H}, \mathrm{s}, \mathrm{ArH}-6^{\prime}\right), 6.15\left(2 \mathrm{H}, \mathrm{s}, \mathrm{OCH}_{2} \mathrm{O}\right), 4.00$ \& 3.98 (each $\left.3 \mathrm{H}, \mathrm{s}, \mathrm{OCH}_{3}\right), 3.63$ $\left(3 \mathrm{H}, \mathrm{s}, \mathrm{OCH}_{3}\right) ; \mathrm{MS} m / z(\%) 367.1(\mathrm{M}+23,40), 299.3(\mathrm{M}-45,100)$.

5.1.1.2 2,2'-Diformyl-4, $\mathbf{4}^{\prime}, 5, \mathbf{5}^{\prime}, 6$-pentamethoxybiphenyl (4b): Starting with 2-bromo veratraldehyde (3b, $200 \mathrm{mg}, 0.82 \mathrm{mmol})$ and $\mathbf{2 a}(310 \mathrm{mg}, 1.29 \mathrm{mmol})$ to afford $207 \mathrm{mg}$ of 4b, 70\% yield, white solid, mp $142-144{ }^{\circ} \mathrm{C} ;{ }^{1} \mathrm{H}$ NMR $\delta \mathrm{ppm} 9.65 \& 9.52$ (each $1 \mathrm{H}, \mathrm{s}, \mathrm{CHO}$ ), $7.76\left(1 \mathrm{H}, \mathrm{s}, \mathrm{ArH}-3^{\prime}\right), 7.40(1 \mathrm{H}, \mathrm{s}, \mathrm{ArH}-3), 6.73\left(1 \mathrm{H}, \mathrm{s}, \mathrm{ArH}-6^{\prime}\right), 4.02 \sim 3.94(12 \mathrm{H}, \mathrm{ms}$, $\left.\mathrm{OCH}_{3} \times 4\right), 3.61\left(3 \mathrm{H}, \mathrm{s}, \mathrm{OCH}_{3}\right) ; \mathrm{MS} \mathrm{m} / z(\%) 383.3(\mathrm{M}+23,50), 315.2(\mathrm{M}-45,100)$.

5.1.1.3.2,2'-Diformyl-4,5,6-trimethoxybiphenyl (4c): Starting with 2-bromobenzaldehyde (3c, $200 \mathrm{mg}, 1.08 \mathrm{mmol})$ and $\mathbf{2 a}(390 \mathrm{mg}, 1.62 \mathrm{mmol})$ to afford $300 \mathrm{mg}$ of $\mathbf{4 c}, 92 \%$ yield, pale-yellow oil; ${ }^{1} \mathrm{H}$ NMR $\delta$ ppm $9.85 \& 9.60$ (each $\left.1 \mathrm{H}, \mathrm{s}, \mathrm{CHO}\right), 8.09(1 \mathrm{H}, \mathrm{d}, J=8.0 \mathrm{~Hz}$, ArH-3'), $7.67 \& 7.60$ (each 1H, t, $\left.J=8.0 \mathrm{~Hz}, \mathrm{ArH}-4^{\prime}, 5^{\prime}\right), 7.42(1 \mathrm{H}, \mathrm{s}, \mathrm{ArH}-3), 7.32(1 \mathrm{H}, \mathrm{d}, J$ $=8.0 \mathrm{~Hz}, \mathrm{ArH}-6), 4.01 \& 3.99\left(\right.$ each $\left.3 \mathrm{H}, \mathrm{s}, \mathrm{OCH}_{3}\right), 3.55\left(3 \mathrm{H}, \mathrm{s}, \mathrm{OCH}_{3}\right) ; \mathrm{MS} m / z(\%) 323.3$ $(\mathrm{M}+23,10), 255.3(\mathrm{M}-45,100)$.

5.1.1.4. 2-Carbomethoxy-2'-formyl-4,5,6-trimethoxybiphenyl (4d): Starting with methyl 2-bromo-3,4,5-trimethoxybenzoate (3d, $500 \mathrm{mg}, 1.64 \mathrm{mmol})$ and 2-formylphenylboronic acid (2b, $295 \mathrm{mg}, 1.97 \mathrm{mmol})$ to afford $326 \mathrm{mg}$ of $\mathbf{4 d}, 60 \%$ yield, pale-yellow oil. ${ }^{1} \mathrm{H}$ NMR $\delta$ ppm $9.84(1 \mathrm{H}, \mathrm{s}, \mathrm{CHO}), 8.23\left(1 \mathrm{H}, \mathrm{d}, J=8.0 \mathrm{~Hz}, \mathrm{ArH}-3^{\prime}\right), 7.60 \& 7.50$ (each $1 \mathrm{H}, \mathrm{t}, J=8.0$ $\left.\mathrm{Hz}, \mathrm{ArH}-4^{\prime}, 5^{\prime}\right), 7.37(1 \mathrm{H}, \mathrm{s}, \mathrm{ArH}-3), 7.19(1 \mathrm{H}, \mathrm{d}, J=8.0 \mathrm{~Hz}$, ArH-6'), 3.97, 3.96, 3.58, and $3.54(12 \mathrm{H}, \mathrm{ms}, \mathrm{OCH} 3 \times 4)$; MS m/z (\%) $271.3(\mathrm{M}-59,40), 256.3(\mathrm{M}-64,100)$.

5.1.1.5. 2,2'-Diformyl-4,5-methylenedioxy-6-methoxybiphenyl (4e): Starting with 2bromo-3-methoxy-4,5-methylenedioxybenzaldehyde (3e, $130 \mathrm{mg}, 0.5 \mathrm{mmol})$ and $\mathbf{2 b}$ (150 $\mathrm{mg}, 1 \mathrm{mmol}$ ) to afford $98 \mathrm{mg}$ of $\mathbf{4 e}, 68 \%$ yield, white solid, $\mathrm{mp} 125-126{ }^{\circ} \mathrm{C} ;{ }^{1} \mathrm{H}-\mathrm{NMR} \delta \mathrm{ppm}$ 9.86 and 9.47 (each 1H, s, CHO), $8.06\left(1 \mathrm{H}, \mathrm{d}, J=7.6 \mathrm{~Hz}, \mathrm{ArH}-3^{\prime}\right), 7.67(1 \mathrm{H}, \mathrm{t}, J=7.6 \mathrm{~Hz}$, ArH-4'), $7.64\left(1 \mathrm{H}, \mathrm{t}, J=7.6 \mathrm{~Hz}, \mathrm{ArH}-5^{\prime}\right), 7.27(1 \mathrm{H}, \mathrm{s}, \mathrm{ArH}-3), 7.25(1 \mathrm{H}, \mathrm{d}, J=7.6 \mathrm{~Hz}$, ArH-6'), $6.13\left(2 \mathrm{H}, \mathrm{s}, \mathrm{CH}_{2}\right), 3.83$ (3H, s, OMe); MS m/z (\%) $307.3(\mathrm{M}+23,45), 239.4(\mathrm{M}-$ $45,100)$.

5.1.1.6. 2,2'-Diformyl-5,6-methylenedioxy-4-methoxybiphenyl (4f): Starting with 2bromo-3,4-methylenedioxy-5-methoxybenzaldehyde $\mathbf{3 f}(129 \mathrm{mg}, 0.5 \mathrm{mmol})$ and $\mathbf{2 b}$ (150 
$\mathrm{mg}, 1.0 \mathrm{mmol}$ ) to afford $100 \mathrm{mg}$ of $\mathbf{4 f}, 70 \%$ yield, white solid, mp $112-114{ }^{\circ} \mathrm{C} ;{ }^{1} \mathrm{H}-\mathrm{NMR} \delta$ ppm 9.95 and 9.68 (each 1H, s, CHO), $8.07\left(1 \mathrm{H}, \mathrm{dd}, J=1.6 \& 7.6 \mathrm{~Hz}, \mathrm{ArH}-3^{\prime}\right), 7.70(1 \mathrm{H}, \mathrm{t}$, $\left.J=7.6 \mathrm{~Hz}, \mathrm{ArH}-4^{\prime}\right), 7.61\left(1 \mathrm{H}, \mathrm{t}, J=7.6 \mathrm{~Hz}, \mathrm{ArH}-5^{\prime}\right), 7.39(1 \mathrm{H}, \mathrm{s}, \mathrm{ArH}-3), 7.37(1 \mathrm{H}, \mathrm{dd}, J=$ $\left.1.6 \& 7.6 \mathrm{~Hz}, \mathrm{ArH}-6^{\prime}\right), 6.13\left(2 \mathrm{H}, \mathrm{s}, \mathrm{OCH}_{2} \mathrm{O}\right), 3.83(3 \mathrm{H}, \mathrm{s}, \mathrm{OMe}), \mathrm{MS} m / z(\%) 307.5(\mathrm{M}+$ $23,20)$.

\subsubsection{General procedure for preparing dibenzocyclooctatetraenes 5a-c-A} mixture of 2,2'-diformylbiphenyl (4a, $\mathbf{4 b}$, or $\mathbf{4} \mathbf{c}, 1$ equiv) and maleimide (1.5 equiv) in anhydrous THF $(5-15 \mathrm{~mL})$ in the presence of $\mathrm{Bu}_{3} \mathrm{P}$ (1.5 equiv) was heated to reflux for 8-12 $\mathrm{h}$ under $\mathrm{N}_{2}$ protection. After removal of solvent, the residue was dissolved in HOAc (3-15 $\mathrm{mL}$ ) and 1-3 drops of piperidine were added. The mixture was heated to $100{ }^{\circ} \mathrm{C}$ for $4-6 \mathrm{~h}$ with TLC monitoring, then poured into ice-water. The solid was filtered and washed with water to neutral, dried, and purified by a flash column (gradual elution: $\mathrm{EtOAc} / \mathrm{H}_{2} \mathrm{Cl}_{2} \mathrm{O} \sim$ $20 \%$ ) to afford corresponding desired pure product.

\subsubsection{1 (5Z,7Z)-10,11-Methylenedioxy-1,2,3-trimethoxydibenzocyclooctatetraene-6,7-} succinimide (5a): Starting with $\mathbf{4 a}(100 \mathrm{mg}, 0.29 \mathrm{mmol})$ to afford $\mathbf{5 a}$, purple solid, $74 \mathrm{mg}$, 62\% yield, mp 266-268 ${ }^{\circ} \mathrm{C} ;{ }^{1} \mathrm{H}$ NMR $\delta \mathrm{ppm} 9.01(1 \mathrm{H}, \mathrm{s},=\mathrm{CH}), 7.77(1 \mathrm{H}, \mathrm{s},=\mathrm{CH}), 7.50$ $(1 \mathrm{H}, \mathrm{br}, \mathrm{NH}), 7.23 \& 7.18$ (each 1H, s, ArH-5 or 12), 6.85 (1H, s, ArH-9), $6.13(2 \mathrm{H}, \mathrm{s}$, $\mathrm{OCH}_{2} \mathrm{O}$ ), 4.04, 3.99, and 3.96 (each $3 \mathrm{H}, \mathrm{s}, \mathrm{OCH}_{3}$ ); ${ }^{13} \mathrm{C}$ NMR (DMSO- $d_{6}$ ) $\delta 172.33,172.20$, $151.89,151.35,149.00,146.59,144.92,142.50,130.21,129.59,126.83,126.56,125.70$, $123.18,118.79,106.35,104.10,103.50,101.81,60.94,60.48,55.80 ; \mathrm{MS} m / z(\%) 408.5(\mathrm{M}$ $+1,100)$.

\subsubsection{2 (5Z,7Z)-1,2,3,10,11-Pentamethoxydibenzocyclooctatetraene-6,7-succinimide} (5b): Starting with $\mathbf{4 b}(1.0 \mathrm{~g}, 2.47 \mathrm{mmol})$ to afford $530 \mathrm{mg}$ of $\mathbf{5 b}, 51 \%$ yield, orange solid, $231-132{ }^{\circ} \mathrm{C},{ }^{1} \mathrm{H}$ NMR (DMSO- $\left.d_{6}\right) \delta \mathrm{ppm} 11.14(1 \mathrm{H}, \mathrm{s}, \mathrm{NH}), 8.97(1 \mathrm{H}, \mathrm{s},=\mathrm{CH}), 7.82(1 \mathrm{H}, \mathrm{s}$, $=\mathrm{CH}), 7.47$ and $7.32($ each $1 \mathrm{H}, \mathrm{s}, \mathrm{ArH}), 7.13(1 \mathrm{H}, \mathrm{s}, \mathrm{ArH}), 4.02 \sim 3.92\left(15 \mathrm{H}, \mathrm{ms}, \mathrm{OCH}_{3} \times\right.$ 5); MS $m / z(\%) 424.2(\mathrm{M}+1,100)$.

\subsubsection{3 (5Z,7Z)-1,2,3-Trimethoxydibenzocyclooctatetraene-6,7-succinimide (5c):}

Starting with $\mathbf{4 c}$ (300 mg, $1 \mathrm{mmol})$ to afford $\mathbf{5 c}$, orange solid, $130 \mathrm{mg}, 31 \%$ yield, $212-214$ ${ }^{\circ} \mathrm{C} ;{ }^{1} \mathrm{H}$ NMR $\delta$ ppm $9.54(1 \mathrm{H}, \mathrm{d}, J=8.4 \mathrm{~Hz}, \mathrm{ArH}), 7.89(2 \mathrm{H}, \mathrm{m}, \mathrm{ArH}), 7.70(1 \mathrm{H}, \mathrm{t}, J=8.4$ $\mathrm{Hz}, \mathrm{ArH}-5), 7.60(2 \mathrm{H}, \mathrm{m}, \mathrm{ArH}, \mathrm{NH}), 7.20 \& 6.88$ (each $1 \mathrm{H}, \mathrm{s},=\mathrm{CH}), 4.06,4.02$, and 3.97 (each $3 \mathrm{H}, \mathrm{s}, \mathrm{OCH}_{3} \times 3$ ); ${ }^{13} \mathrm{C}$ NMR (DMSO- $\left.d_{6}\right) \delta 172.66,172.55,152.86,152.53,145.27$, $143.25,131.20,130.61,130.48,129.95,129.90,128.79,127.57,126.73,126.65,125.45$, $118.95,104.33,61.33,60.86,56.28 ; \mathrm{MS} m / z(\%) 386.2(\mathrm{M}+23,70), 364.3(\mathrm{M}+1,100)$.

\subsubsection{1 (5Z,7Z)-6,7-Dicarbomethoxy-10,11-methylenedioxy-1,2,3-trimethoxydibenzo-} cyclooctatetraene (6a): To a solution of $4 \mathbf{a}(50 \mathrm{mg}, 0.15 \mathrm{mmol})$ in THF $(2-3 \mathrm{~mL})$ was added dimethyl maleate $(0.07 \mathrm{~mL}, 0.56 \mathrm{mmol})$ and $\mathrm{Bu}_{3} \mathrm{P}(0.14 \mathrm{~mL}, 0.56 \mathrm{mmol})$ in a sealed tube $(10 \mathrm{~mL})$. The mixture was heated to $100{ }^{\circ} \mathrm{C}$ under microwave irradiation for $2 \mathrm{~h}$, and then cooled to room temperature, diluted with EtOAc, and washed with water several times. After removal of solvent in vacuo, the residue was purified on a flash column (gradual elution: EtOAc/petroleum ether $0 \sim 60 \%$ ). The obtained intermediate was re-dissolved in dried benzene (ca. $10 \mathrm{~mL}$ ) and 3 drops of piperidine and HOAc were added. The mixture was heated to reflux for $24 \mathrm{~h}$ under $\mathrm{N}_{2}$ protection equipped with a distillation trap to remove water produced during reaction. After removal of solvent in vacuo, the residue was purified on a flash column (gradual elution: EtOAc/petroleum ether $0 \sim 50 \%$ ) and crystallized from $\mathrm{MeOH}$ to afford $30 \mathrm{mg}$ of $\mathbf{6 a}, 45 \%$ yield, pale-yellow needles, $146-148{ }^{\circ} \mathrm{C} .{ }^{1} \mathrm{H}$ NMR $\delta \mathrm{ppm}$ $8.99(1 \mathrm{H}, \mathrm{s},=\mathrm{CH}), 7.57(1 \mathrm{H}, \mathrm{s},=\mathrm{CH}), 7.40 \& 7.19($ each $1 \mathrm{H}, \mathrm{s}, \mathrm{ArH}), 6.27(1 \mathrm{H}, \mathrm{s}, \mathrm{ArH})$, 
$6.11\left(2 \mathrm{H}, \mathrm{s}, \mathrm{OCH}_{2} \mathrm{O}\right), 4.03,3.99$ and $3.98\left(\right.$ each $\left.3 \mathrm{H}, \mathrm{s}, \mathrm{OCH}_{3} \times 3\right), 3.85$ and 3.84 (each $3 \mathrm{H}$, $\left.\mathrm{s}, \mathrm{OCH}_{3} \times 2\right) ; \mathrm{MS} \mathrm{m} / z(\%) 455.4(\mathrm{M}+1,50), 423.4(\mathrm{M}-31,100)$.

\subsubsection{2 (5Z,7Z)-6,7-Dicarbomethoxy-1,2,3,10,11-pentamethoxydibenzocyclooc}

tatetraene (6b): The procedure was the same as that of 6a Starting with $\mathbf{4 b}(100 \mathrm{mg}, 0.28$ mmol) to afford $54 \mathrm{mg}$ of $\mathbf{6 b}, 41 \%$ yield, pale-yellow needles, $126-128{ }^{\circ} \mathrm{C} .{ }^{1} \mathrm{H}$ NMR $\delta \mathrm{ppm}$ $9.16(1 \mathrm{H}, \mathrm{s},=\mathrm{CH}), 7.57(1 \mathrm{H}, \mathrm{s},=\mathrm{CH}), 7.56,7.09$ and $6.29($ each $1 \mathrm{H}, \mathrm{s}, \mathrm{ArH}), 4.10$ and 4.05 (each $\left.3 \mathrm{H}, \mathrm{s}, \mathrm{OCH}_{3}\right), 4.03 \sim 4.00\left(9 \mathrm{H}, \mathrm{ms}, \mathrm{OCH}_{3} \times 3\right), 3.86$ and 3.84 (each $3 \mathrm{H}, \mathrm{s}, \mathrm{CO}_{2} \mathrm{CH}_{3} \times$ 2); $\mathrm{MS} m / z(\%) 471.5(\mathrm{M}+1,40), 439.4(\mathrm{M}-31,100)$.

\subsection{4 (5Z, 7Z)-6,7-Dicarboxy-10,11-methylenedioxy-1,2,3-} trimethoxydibenzocyclooctatetraene (7)—A solution of $5 \mathbf{a}(50 \mathrm{mg}, 0.12 \mathrm{mmol})$ in THF (2-3 mL) in the presence of a few drops of aq $\mathrm{NaOH}(10 \%)$ was heated to $50{ }^{\circ} \mathrm{C}$ for 1 h. The mixture was then poured into ice-water, acidified $\mathrm{pH}$ to $1-2$ with aq $\mathrm{HCl}(5 \%)$, extracted with EtOAc three times, and washed with water to neutral. After removal of solvent in vacuo, residue was purified on a flash column (gradual elution: $\mathrm{MeOH} / \mathrm{CH}_{2} \mathrm{Cl}_{2}$ with $3 \%$ HOAc $0 \sim 20 \%$ ) to afford 7 as a brown solid, $28 \mathrm{mg}, 54 \%$ yield, $\mathrm{mp}>200{ }^{\circ} \mathrm{C}$ (des); ${ }^{1} \mathrm{H}$ NMR (DMSO- $\left.d_{6}\right) \delta$ ppm $8.82(1 \mathrm{H}, \mathrm{s},=\mathrm{CH}), 7.67(1 \mathrm{H}, \mathrm{s},=\mathrm{CH}), 7.50,7.36,7.36$ and $6.27(\mathrm{each} 1 \mathrm{H}, \mathrm{s}, \mathrm{ArH}), 6.20\left(2 \mathrm{H}, \mathrm{s}, \mathrm{OCH}_{2} \mathrm{O}\right), 3.90\left(6 \mathrm{H}, \mathrm{s}, \mathrm{OCH}_{3} \times 2\right), 3.88(3 \mathrm{H}, \mathrm{s}$, $\left.\mathrm{OCH}_{3}\right) ; \mathrm{MS} m / z(\%) 427.2(\mathrm{M}+1,100)$.

5.1.5 General procedure for preparing nitrovinylbiphenyls (8d, 8e, 9a, 9d, 10a, $11 \mathrm{a}$, and 11b)—A mixture of a diformyl or monoformylbiphenyl compound $(4,100 \mathrm{mg})$ and nitroethane or nitromethane $(1 \mathrm{~mL}$, excess $)$ in toluene $(5-7 \mathrm{~mL})$ in the presence of icecold HOAc $(0.03 \mathrm{~mL})$ and $n$-butylamine $(0.02 \mathrm{~mL})$ was heated at $100-120{ }^{\circ} \mathrm{C}$ for $3-4$ days. The mixture was poured into ice-water, extracted with EtOAc, and dried over $\mathrm{Na}_{2} \mathrm{SO}_{4}$. After removal of solvent in vacuo, the residue was purified by thin plate chromatography (TLC) eluted with $\mathrm{CH}_{2} \mathrm{Cl}_{2}$ or benzene/EtOAc (100:2) to obtain desired products.

5.1.5.1. (E)-2,2'-Dinitrovinyl-4,5,6-trimethoxybiphenyl (8d): Starting with $\mathbf{4 c}(100 \mathrm{mg})$ and nitromethane (excess) to afford $8 \mathbf{d}$ in $70 \%$ yield, yellow solid, mp $148-150{ }^{\circ} \mathrm{C} ;{ }^{1} \mathrm{H}-$ NMR $\delta$ ppm $8.16(1 \mathrm{H}, \mathrm{d}, J=7.6 \mathrm{~Hz},=\mathrm{CH}), 7.92(1 \mathrm{H}, \mathrm{d}, J=7.6 \mathrm{~Hz}, \mathrm{ArH}), 7.50-7.55(3 \mathrm{H}$, $\mathrm{m}, \mathrm{ArH}), 6.72(1 \mathrm{H}, \mathrm{s}, \mathrm{ArH}), 5.47(1 \mathrm{H}, \mathrm{dt}, J=2.0$ and $8.4 \mathrm{~Hz},=\mathrm{CH}), 4.06-4.18(2 \mathrm{H}, \mathrm{m}$, $\left.=\mathrm{CHNO}_{2}\right), 3.94,3.92$ and 3.47 (each $\left.3 \mathrm{H}, \mathrm{s}, \mathrm{OMe}\right)$; MS $\mathrm{m} / z(\%) 326.1(\mathrm{M}+1,100)$.

5.1.5.2. (E)-2-Carbomethoxy-2'-(2-methylnitrovinyl)-4,5,6-trimethoxybiphenyl (8e): Starting with $4 \mathbf{c}(100 \mathrm{mg})$ and nitroethane (excess) to afford $8 \mathbf{e}$ in $57 \%$ yield, yellow oil; ${ }^{1} \mathrm{H}$ NMR $\delta \mathrm{ppm} 7.76(1 \mathrm{H}, \mathrm{s},=\mathrm{CH}), 7.43(2 \mathrm{H}, \mathrm{m}, \mathrm{ArH} \times 2), 7.31(3 \mathrm{H}, \mathrm{m}, \mathrm{ArH} \times 2$, and $=\mathrm{CH})$, $7.30(1 \mathrm{H}, \mathrm{s}, \mathrm{ArH}-3), 3.96\left(3 \mathrm{H}, \mathrm{s}, \mathrm{OCH}_{3}\right), 3.93\left(3 \mathrm{H}, \mathrm{s}, \mathrm{OCH}_{3}\right), 3.55\left(3 \mathrm{H}, \mathrm{s}, \mathrm{OCH}_{3}\right), 3.53(3 \mathrm{H}$, $\left.\mathrm{s}, \mathrm{OCH}_{3}\right), 2.33\left(3 \mathrm{H}, \mathrm{s}, \mathrm{CH}_{3}\right) ; \mathrm{MS} m / z(\%) 388.2(\mathrm{M}+1,60)$.

5.1.5.3 (E)-2,2-Di(2-methylnitrovinnyl)-4',5'-methylenedioxy-4,5,6-trimethoxybiphenyl (9a): Starting with $\mathbf{4 a}(100 \mathrm{mg})$ and nitroethane (excess) to afford 9 a in $37 \%$ yield, yellow solid, mp 98-99 ${ }^{\circ} \mathrm{C} ;{ }^{1} \mathrm{H}-\mathrm{NMR} \delta \mathrm{ppm} 8.05(1 \mathrm{H}, \mathrm{s}, \mathrm{CH}=), 7.47(1 \mathrm{H}, \mathrm{s}, \mathrm{CH}=), 6.87(1 \mathrm{H}, \mathrm{s}$, $\mathrm{ArH}), 6.75(1 \mathrm{H}, \mathrm{s}, \mathrm{ArH}), 6.66(1 \mathrm{H}, \mathrm{s}, \mathrm{ArH}), 6.13\left(2 \mathrm{H}, \mathrm{s}, \mathrm{OCH}_{2} \mathrm{O}\right), 3.95 \sim 3.90(9 \mathrm{H}, \mathrm{ms}$, $\left.\mathrm{OCH}_{3}\right), 2.50\left(3 \mathrm{H}, \mathrm{s}, \mathrm{CH}_{3}\right), 2.29$ (3H, s, $\left.\mathrm{CH}_{3}\right) ; \mathrm{MS} \mathrm{m} / z(\%) 459.2(\mathrm{M}+1,95), 384.2$ (100).

\subsubsection{4. (E)-2,2'-Dinitrovinyl-4,5'-methylenedioxy-4,5,6-trimethoxybiphenyl (9d):}

Starting with $\mathbf{4 a}(100 \mathrm{mg}$ ) and nitromethane (excess) to afford $\mathbf{9 d}$ in $72 \%$ yield, yellow solid, mp $114-115{ }^{\circ} \mathrm{C} ;{ }^{1} \mathrm{H}-\mathrm{NMR} \delta \mathrm{ppm} 8.04(1 \mathrm{H}, \mathrm{s}, \mathrm{ArH}), 7.24(2 \mathrm{H}, \mathrm{d}, J=12.8 \mathrm{~Hz},=\mathrm{CH}), 6.83$ $(2 \mathrm{H}, \mathrm{d}, J=12.8 \mathrm{~Hz},=\mathrm{CH}), 6.05$ and $6.00($ each $1 \mathrm{H}, \mathrm{s}, \mathrm{ArH}), 4.28\left(2 \mathrm{H}, \mathrm{m}, \mathrm{OCH}_{2} \mathrm{O}\right), 4.05$, 
3.96, and 3.51 (each 3H, s, OMe); MS m/z (\%) $431.1(\mathrm{M}+1,10), 453.2(\mathrm{M}+\mathrm{Na}, 50), 370.0$ (100).

5.1.5.5. (E)-2,2'-Di(2-methylnitrovinyl)-4, $\mathbf{4}^{\prime}, 5,5^{\prime}, 6$-pentamethoxybiphenyl (10a): Starting with $\mathbf{4 b}(100 \mathrm{mg})$ and nitroethane (excess) to afford 10a in $27 \%$ yield, yellow oil; ${ }^{1} \mathrm{H}-\mathrm{NMR}$ $\delta \mathrm{ppm} 7.53(1 \mathrm{H}, \mathrm{s},=\mathrm{CH}), 7.36(1 \mathrm{H}, \mathrm{s},=\mathrm{CH}), 6.75-6.87(2 \mathrm{H}, \mathrm{m}, \mathrm{ArH}), 6.59(1 \mathrm{H}, \mathrm{s}, \mathrm{ArH})$, 3.87-3.97 (18H, ms, $\left.\mathrm{OCH}_{3} \times 5,=\mathrm{CCH}_{3}\right), 3.60\left(3 \mathrm{H}, \mathrm{s}, \mathrm{CH}_{3}\right) ; \mathrm{MS} m / z(\%) 497.3(\mathrm{M}+\mathrm{Na}$, $100)$.

5.1.5.6 (E)-2,2'-Di(2-methylnitrovinyl)-6-methoxy-4,5-methylenedioxybiphenyl (11a): Starting with $4 \mathbf{e}(95 \mathrm{mg}, 0.33 \mathrm{mmol})$ and nitroethane (10 mL, excess) to give $54 \mathrm{mg}$ of 11a, $41 \%$ yield, yellow oil; ${ }^{1} \mathrm{H}$ NMR $\delta$ ppm $7.74(1 \mathrm{H}, \mathrm{s},=\mathrm{CH}), 7.46 \sim 7.21(4 \mathrm{H}, \mathrm{m}, \mathrm{ArH}), 6.69$ $(1 \mathrm{H}, \mathrm{s},=\mathrm{CH}), 6.02(1 \mathrm{H}, \mathrm{s}, \mathrm{ArH}), 4.62\left(2 \mathrm{H}, \mathrm{s}, \mathrm{OCH}_{2} \mathrm{O}\right), 3.79\left(3 \mathrm{H}, \mathrm{s}, \mathrm{OCH}_{3}\right), 2.36(3 \mathrm{H}, \mathrm{s}$, $\left.\mathrm{CH}_{3}\right), 1.97\left(3 \mathrm{H}, \mathrm{s}, \mathrm{CH}_{3}\right) ; \mathrm{MS} \mathrm{m} / z(\%) 399.2(\mathrm{M}+1,20)$.

5.1.5 7 (E)-2,2'-Di(2-methylnitrovinyl)-4-methoxy-5,6-methylenedioxybiphenyl (11b): Starting with $\mathbf{4 f}(50 \mathrm{mg}, 0.18 \mathrm{mmol})$ and nitroethane $(10 \mathrm{~mL})$ to give $40 \mathrm{mg}$ of $\mathbf{1 1 b}, 57 \%$ yield, yellow oil, ${ }^{1} \mathrm{H}-\mathrm{NMR} \delta \mathrm{ppm} 7.68(1 \mathrm{H}, \mathrm{s},=\mathrm{CH}), 7.51 \sim 7.36(4 \mathrm{H}, \mathrm{m}, \mathrm{ArH}), 6.61(1 \mathrm{H}, \mathrm{s}$, $=\mathrm{CH}), 6.07(1 \mathrm{H}, \mathrm{s}, \mathrm{ArH}), 5.98\left(2 \mathrm{H}, \mathrm{s}, \mathrm{OCH}_{2} \mathrm{O}\right), 3.98\left(3 \mathrm{H}, \mathrm{s}, \mathrm{OCH}_{3}\right), 2.30\left(3 \mathrm{H}, \mathrm{s}, \mathrm{CH}_{3}\right), 2.26$ $\left(3 \mathrm{H}, \mathrm{s}, \mathrm{CH}_{3}\right) ; \mathrm{MS} \mathrm{m} / z$ (\%) $399.2(\mathrm{M}+1,30)$.

\subsubsection{General procedure of preparing (2-carboethoxy)cyanovinylbiphenyls} (8b, 8f, 9b, 10b)—A solution of a formylbiphenyl $4(50 \mathrm{mg})$ and ethyl cyanoacetate $(0.1$ $\mathrm{mL})$ in HOAc $(3 \mathrm{~mL})$ in the presence of 3 drops of piperidine was heated to $100{ }^{\circ} \mathrm{C}$ with stirring under $\mathrm{N}_{2}$ protection for $6-8 \mathrm{~h}$. The mixture was poured into ice-water, extracted with EtOAc, and washed with water to neutral. After removal of solvent in vacuo, the residue was simply washed with $\mathrm{MeOH}$ or purified on a flash column (gradual elution: EtOAc/petroleum ether $0 \sim 40 \%$ ) or thin plate chromatography (elution: cyclohexane/ EtOAc 5:2) to afford pure product.

5.1.6.1. (E)-2,2'-Di(2-carbomethoxy)cyanovinyl-4,5,6-trimethoxybiphenyl (8b): Starting with $4 \mathbf{c}(50 \mathrm{mg})$ and ethyl cyanoacetate $(0.1 \mathrm{~mL})$ to give $\mathbf{8 b}$ in $50 \%$ yield, pale yellow oil; ${ }^{1} \mathrm{H}$ NMR $\delta$ ppm $8.40\left(1 \mathrm{H}, \mathrm{m}, \mathrm{ArH}-3^{\prime}\right), 7.93(1 \mathrm{H}, \mathrm{s}, \mathrm{ArH}-3), 7.84 \& 7.73$ (each 1H, s, $=\mathrm{CH}), 7.60\left(2 \mathrm{H}, \mathrm{m}, \mathrm{ArH}-4^{\prime}, 5^{\prime}\right), 7.23\left(1 \mathrm{H}, \mathrm{m}, \mathrm{ArH}-6^{\prime}\right), 4.28\left(4 \mathrm{H}, \mathrm{m}, \mathrm{OCH}_{2} \times 2\right), 4.01,4.00$ \& 3.54 (each $\left.3 \mathrm{H}, \mathrm{s}, \mathrm{OCH}_{3} \times 3\right), 1.32\left(6 \mathrm{H}, \mathrm{m}, \mathrm{CH}_{3} \times 2\right) ; \mathrm{MS} / z(\%) 513.5(\mathrm{M}+23,50)$, $445.2(\mathrm{M}-45,100)$.

\subsubsection{2-Carbomethoxy-2'-(2-carbomethoxy)cyanovinyl-4,5,6-trimethoxybiphenyl} (8f): Starting with $\mathbf{4 d}(50 \mathrm{mg})$ and ethyl cyanoacetate $(0.1 \mathrm{~mL})$ to give $\mathbf{8 f}$ in $58 \%$ yield, colorless oil; ${ }^{1} \mathrm{H}$ NMR $\delta$ ppm $8.40\left(1 \mathrm{H}, \mathrm{d}, J=8.0 \mathrm{~Hz}, \mathrm{ArH}-3^{\prime}\right), 8.06(1 \mathrm{H}, \mathrm{s},=\mathrm{CH}), 7.52(2 \mathrm{H}$, $\left.\mathrm{m}, \mathrm{ArH}-4^{\prime}, 5^{\prime}\right), 7.35(1 \mathrm{H}, \mathrm{s}, \mathrm{ArH}-3), 7.21\left(1 \mathrm{H}, \mathrm{d}, J=8.0 \mathrm{~Hz}, \mathrm{ArH}-6^{\prime}\right), 4.28(2 \mathrm{H}, \mathrm{q}, J=8.0$ $\left.\mathrm{Hz}, \mathrm{CH}_{2}\right), 3.97$ and $3.95\left(\right.$ each $\left.3 \mathrm{H}, \mathrm{s}, \mathrm{OCH}_{3} \times 2\right), 3.53\left(6 \mathrm{H}, \mathrm{s}, \mathrm{OCH}_{3} \times 2\right), 1.32(3 \mathrm{H}, \mathrm{t}, J=$ $\left.8.0 \mathrm{~Hz}, \mathrm{CH}_{3}\right) ; \mathrm{MS} \mathrm{m} / z(\%) 448.4(\mathrm{M}+23,20), 348.2(\mathrm{M}-77,100)$.

5.1.6.3. (E)-2,2'-Di(2-carbomethoxy)cyanovinyl-4', 5'-methylenedioxy-4,5,6trimethoxybiphenyl (9b): Starting with $\mathbf{4 a}(50 \mathrm{mg})$ and ethyl cyanoacetate $(0.1 \mathrm{~mL})$ to give 9b in 50\% yield, white needles, mp 66-68 ${ }^{\circ} \mathrm{C} ;{ }^{1} \mathrm{H}$ NMR $\delta \mathrm{ppm} 7.90(1 \mathrm{H}, \mathrm{s}, \mathrm{ArH}), 6.81(1 \mathrm{H}$, $\mathrm{s}, \mathrm{ArH}), 6.63(1 \mathrm{H}, \mathrm{s}, \mathrm{ArH}), 6.03$ and $6.01($ each $1 \mathrm{H}, \mathrm{s},=\mathrm{CH}), 4.52$ and 4.44 (each $2 \mathrm{H}, \mathrm{m}$, $\left.\mathrm{OCH}_{2} \times 2\right), 3.92\left(6 \mathrm{H}, \mathrm{s}, \mathrm{OCH}_{3} \times 2\right), 3.80 \sim 3.70\left(5 \mathrm{H}, \mathrm{m}, \mathrm{OCH}_{2} \mathrm{O}, \mathrm{OCH}_{3}\right), 1.44(6 \mathrm{H}, \mathrm{t}$, $\left.\mathrm{CH}_{2} \mathrm{CH} 3 \times 2\right) ; \mathrm{MS} m / z(\%) 557.3(\mathrm{M}+23,95), 552.5(\mathrm{M}+18,100), 535.4(\mathrm{M}+1,80)$. 
5.1.6.4. (E)-2,2'-Di(2-carbomethoxy)cyanovinyl-4, $4^{\prime}, 5,5^{\prime}, 6$-pentamethoxybiphenyl (10b): Starting with $\mathbf{4 b}(50 \mathrm{mg})$ and ethyl cyanoacetate $(0.1 \mathrm{~mL})$ to give $10 \mathrm{~b}$ in $52 \%$ yield, white solid, mp 96-98 ${ }^{\circ} \mathrm{C} ;{ }^{1} \mathrm{H}$ NMR $\delta$ ppm $8.16\left(1 \mathrm{H}, \mathrm{s}, \mathrm{ArH}-3^{\prime}\right), 7.84(1 \mathrm{H}, \mathrm{s}, \mathrm{ArH}-3), 7.81$ and $7.74($ each $1 \mathrm{H}, \mathrm{s},=\mathrm{CH} \times 2), 6.68\left(1 \mathrm{H}, \mathrm{s}, \mathrm{ArH}-6^{\prime}\right), 4.30 \sim 4.26\left(4 \mathrm{H}, \mathrm{m}, \mathrm{OCH}_{2} \times 2\right), 4.04$ $\left(3 \mathrm{H}, \mathrm{s}, \mathrm{OCH}_{3}\right), 4.01\left(6 \mathrm{H}, \mathrm{s}, \mathrm{OCH}_{3} \times 2\right), 3.91$ and $3.58\left(\right.$ each $\left.3 \mathrm{H}, \mathrm{s}, \mathrm{OCH}_{3} \times 2\right), 1.32(6 \mathrm{H}, \mathrm{t}, J$ $\left.=8.0 \mathrm{~Hz}, \mathrm{CH}_{3} \times 2\right) ;{ }^{13} \mathrm{C} \mathrm{NMR}\left(\mathrm{CDCl}_{3}\right) \delta 162.72,161.12,153.73,152.62,152.49,151.48$, $149.17,146.26,132.80,129.23,126.32,124.22,116.28,115.76,114.38,110.28,107.59$, 103.24, 100.64, 67.78, 62.55, 61.36, 61.09, 56.37, 56.30, 14.17, 14.13; MS m/z (\%) 551.4 $(M+1,20), 573.5(M+23,50)$.

5.1.7. General procedure for preparing 2,2'-dicyanovinyl)biphenyls (8c, $8 \mathrm{~g}, 9 \mathrm{c}$, and 10c) - A solution of di- or mono-formylbiphenyl 4 (1 equiv) and malononitrile (4 equiv) in $\mathrm{CH}_{3} \mathrm{CN}(5 \mathrm{~mL})$ in the presence of $\mathrm{NH}_{4} \mathrm{OAc}(100 \mathrm{mg})$ was heated to $60{ }^{\circ} \mathrm{C}$ with stirring under $\mathrm{N}_{2}$ protection for $6-8 \mathrm{~h}$. The mixture was poured into ice-water, extracted with EtOAc, washed with water and brine successively. After removal of solvent in vacuo, the residue was purified on a flash column (gradual elution: EtOAc/petroleum ether $0 \sim$ $40 \%)$ to afford desired pure product.

5.1.7.1. 2,2'-Di(2,2'-dicyanovinyl)-4,5,6-trimethoxybiphenyl (8c): Starting with $4 \mathrm{~b}$ (50 $\mathrm{mg}$ ) and malononitrile to provide $8 \mathbf{c}$ in $47 \%$ yield, white solid, $\mathrm{mp} 178-180{ }^{\circ} \mathrm{C} ;{ }^{1} \mathrm{H}$ NMR $\delta$ ppm 8.34 (1H, d, $\left.J=8.0 \mathrm{~Hz}, \mathrm{ArH}-3^{\prime}\right), 7.81$ (1H, s, ArH-3), $7.71 \sim 7.67$ (2H, m, ArH-4', 5'), $7.47(1 \mathrm{H}, \mathrm{s},=\mathrm{CH}), 7.25(1 \mathrm{H}, \mathrm{s},=\mathrm{CH}), 7.22\left(1 \mathrm{H}, \mathrm{d}, J=8.0 \mathrm{~Hz}, \mathrm{ArH}-6^{\prime}\right), 4.06,4.02$, and 3.53 (each $\left.3 \mathrm{H}, \mathrm{s}, \mathrm{OCH}_{3} \times 3\right) ; \mathrm{MS} \mathrm{m} / z(\%) 419.3(\mathrm{M}+23,100), 397.2(\mathrm{M}+1,10)$.

5.1.7.2. 2-Carbomethoxy-2'-(2,2-dicyanovinyl)-4,5,6-trimethoxybiphenyl (8g): Starting with $\mathbf{4 d}(50 \mathrm{mg}$ ) and malononitrile to provide $\mathbf{8 g}$ in 70\% yield, white solid, $\mathrm{mp}$ 102-104 ${ }^{\circ} \mathrm{C} ;{ }^{1} \mathrm{H}$ NMR $\delta$ ppm $8.30\left(1 \mathrm{H}, \mathrm{d}, J=8.0 \mathrm{~Hz}, \mathrm{ArH}-3^{\prime}\right), 7.61 \sim 7.51(3 \mathrm{H}, \mathrm{m}, \mathrm{ArH}), 7.38(1 \mathrm{H}$, $\mathrm{s},=\mathrm{CH}), 7.23\left(1 \mathrm{H}, \mathrm{d}, J=8.0 \mathrm{~Hz}, \mathrm{ArH}-6^{\prime}\right), 3.99,3.98,3.58$ and $3.54\left(\right.$ each $\left.3 \mathrm{H}, \mathrm{s}, \mathrm{OCH}_{3} \times 4\right)$; MS $m / z(\%) 401.4(\mathrm{M}+23,50), 288.2(\mathrm{M}-90,100)$.

5.1.7.3. 2,2'-Di(2,2'-dicyanovinyl)-4' $\mathbf{2}^{\prime}, \mathbf{5}^{\prime}$-methylenedioxy-4,5,6-trimethoxybiphenyl (9c): Starting with $\mathbf{4 a}(50 \mathrm{mg})$ and malononitrileto provide $9 \mathbf{c}$ in $58 \%$ yield, light yellow solid, $\mathrm{mp}$ 172-174 ${ }^{\circ} \mathrm{C} ;{ }^{1} \mathrm{H}$ NMR $\delta$ ppm $7.94\left(1 \mathrm{H}, \mathrm{s}, \mathrm{ArH}-3{ }^{\prime}\right), 7.80(1 \mathrm{H}, \mathrm{s},=\mathrm{CH}), 7.24(1 \mathrm{H}, \mathrm{s},=\mathrm{CH})$, 7.18 and 6.65 (each $1 \mathrm{H}, \mathrm{s}, \mathrm{ArH}), 6.25\left(2 \mathrm{H}, \mathrm{d}, J=8.0 \mathrm{~Hz}, \mathrm{OCH}_{2} \mathrm{O}\right), 4.05$ and 4.02 (each $3 \mathrm{H}$, $\left.\mathrm{s}, \mathrm{OCH}_{3} \times 2\right), 3.63(3 \mathrm{H}, \mathrm{s}, \mathrm{OCH} 3)$; $\mathrm{MS} m / z(\%) 463.3(\mathrm{M}+23,90), 458.4(\mathrm{M}+18,100)$.

5.1.7.4. 2,2'-Di(2,2'-dicyanovinyl)-4', $\mathbf{5}^{\prime}, 4,5,6$-pentamethoxybiphenyl (10c): Starting with 4b $(50 \mathrm{mg})$ and malononitrile to provide 10c in 40\% yield, light yellow solid, mp 103-104 ${ }^{\circ} \mathrm{C} ;{ }^{1} \mathrm{H}$ NMR $\delta$ ppm $8.07\left(1 \mathrm{H}, \mathrm{s}, \mathrm{ArH}-3{ }^{\prime}\right), 7.81(1 \mathrm{H}, \mathrm{s}, \mathrm{ArH}-3), 7.23(1 \mathrm{H}, \mathrm{s},=\mathrm{CH}), 7.21(1 \mathrm{H}$, $\mathrm{s},=\mathrm{CH}), 6.62\left(1 \mathrm{H}, \mathrm{s}, \mathrm{ArH}-6^{\prime}\right), 4.07 \sim 4.02\left(9 \mathrm{H}, \mathrm{ms}, \mathrm{OCH}_{3} \times 3\right), 3.96\left(3 \mathrm{H}, \mathrm{s}, \mathrm{OCH}_{3}\right), 3.61$ $\left(3 \mathrm{H}, \mathrm{s}, \mathrm{OCH}_{3}-6\right)$; $\mathrm{MS} m / z(\%) 479.2(\mathrm{M}+23,95)$.

\subsection{Bioassays}

5.2.1. Anti-tumor activity against tumor cell lines in HTCL assay-Target compounds were assayed for in vitro anticancer activity by using the SRB method according to procedures described previously ${ }^{14,15,19}$ The panel of cell lines included human lung carcinoma (A-549), epidermoid carcinoma of the nasopharynx (KB), P-gp-expressing epidermoid carcinoma of the nasopharynx (KBvin), and prostate cancer (DU145). The cytotoxic effects of each compound were expressed as $\mathrm{GI}_{50}$ values, which represent the molar drug concentrations required to cause 50\% tumor cell growth inhibition. 
5.2.2. NF-KB luciferase reporter gene assays-The effect of the tested compounds on LPS-induced NF- $\kappa B$ activity was measured using RAW264.7 cells stably transfected with an NF- $\kappa B$ luciferase reporter construct. Cells were seeded at $10^{4}$ cells per well in a 96well plate overnight for attachment, then cells were pretreated with 5a or BAY11-7082 for 30 min before being stimulated with LPS for $6 \mathrm{~h}$. The treated cells were harvested and lysed, and the firefly luciferase activities in lysates were measured using the Promega Luciferase Assay System according to manufacturer's instructions (Promega).

5.2.3. Protein isolation and Western blot analysis-RAW264.7 cells were seeded in petri-dishes and incubated overnight for attachment. Cells were incubated with LPS $(1 \mu \mathrm{g} /$ $\mathrm{mL}$ ) for $15 \mathrm{~min}$. In order to study the effects of the inhibitor, cells were pretreated with either 5a $(2.5,5$, and $10 \mu \mathrm{M})$ or BAY11-7082 $(20 \mu \mathrm{M})$ for 30 min prior to treatment with LPS. The total protein was isolated from cells in radio-immunoprecipitation assay buffer containing protease and phosphatase inhibitors. The nuclear and cytosolic extracts were isolated by using the Nuclear Extraction Kit (Cayman) according to the manufacturer's recommendations. The proteins were then subjected to Western blot analysis. Briefly equal amounts of protein were resolved with SDS-PAGE and transferred to PVDF membranes (Roche). The membranes were probed with primary antibodies overnight at $4{ }^{\circ} \mathrm{C}$ and incubated for $1 \mathrm{~h}$ with secondary peroxidase-conjugated antibod y at room temperature. The signals on the membrane were visualized by Lumiglo reagent (Cell Signaling) and exposed to X-ray film (Fuji Photo Film).

5.2.4 Nitric oxide determination-The measurement of $\mathrm{NO}_{2}^{-}$in the cell culture medium was carried out by using Griess reagents I and II (Beyotime), as a measure of NO production. Briefly RAW264.7 cells were seeded in petri-dishes and incubated overnight for attachment. Cells were stimulated by LPS $(1 \mu \mathrm{g} / \mathrm{mL})$ for $18 \mathrm{~h}$. In order to study the effects of the inhibitor, cells were pretreated with either $5 \mathbf{a}(0.6,1.25$ and $2.5 \mu \mathrm{M})$ or BAY 11-7082 $(20 \mu \mathrm{M})$ for $30 \mathrm{~min}$ prior to treatment with LPS. After treatment, the cells culture medium was collected and centrifuged $(69 \times \mathrm{g} / 5 \mathrm{~min})$. Griess reagents I and II were equilibrated to room temperature before use. Fifty-microliter volumes of cell culture supernatants were reacted with Griess reagent I $(50 \mu \mathrm{L})$ and Griess reagent II $(50 \mu \mathrm{L})$. Finally, absorbance was measured at $540 \mathrm{~nm}$.

\subsection{Conformation search method}

Conformation searching was performed by Discovery Studio 3.0 software (Accelrys, Inc.). The default atom types and parameters supplied with Discovery Studio 3.0 were used throughout the conformation searching. Before search, all target compounds were assigned to the same configuration where the phenyl-A ring rotates clockwise and the phenyl-B ring rotates counter-clockwise along the biphenyl axis. Small molecules were prepared using the ligand preparation tool available in the software and then systematic search conformation method was deployed by generate conformations tool with default CHARMm force-field. The indicated torsion angle and absolute energy of the global minimum were measured.

\section{Supplementary Material}

Refer to Web version on PubMed Central for supplementary material.

\section{Acknowledgments}

This investigation was supported by grants 81120108022 and 30930106 from the Natural Science Fundation of China (NSFC) awarded to L. Xie and U.S. NIH grant awarded to K. H. Lee (CA177584). This study was also supported in part by the Taiwan Department of Health, China Medical University Hospital Cancer Research Center of Excellence (DOH100-TD-C-111-005). 


\section{References}

1. Charlton JL. J Nat Prod. 1998; 61:1447. [PubMed: 9834179]

2. Lee KH. J Nat Prod. 2004; 67:273. [PubMed: 14987069]

3. Kende AS, Liebeskind LS. J Am Chem Soc. 1976; 98:267. [PubMed: 1244373]

4. Hughes LR, Raphael RA. Tetrahedron Lett. 1976; 17:1543.

5. Mitra S, Gurrala SR, Coleman RS. J Org Chem. 2007; 72:8724. [PubMed: 17929867]

6. Singidi RR, RajanBabu TV. Org Lett. 2008; 10:3351. [PubMed: 18610976]

7. Chen WW, Zhao Q, Xu MH, Lin GQ. Org Lett. 2010; 12:1072. [PubMed: 20112963]

8. Chen DF, Zhang SX, Xie L, Xie JX, Chen K, Kashiwada Y, Zhou BN, Wang P, Cosentino LM, Lee KH. Bioorg Med Chem. 1997; 5:1715. [PubMed: 9313872]

9. Wu G, Guo HF, Gao K, Liu YN, Bastow KF, Morris-Natschke SL, Lee KH, Xie L. Bioorg Med Chem Lett. 2008; 18:5272. [PubMed: 18782668]

10. Basseresm DS, Baldwin AS. Oncogene. 2006; 25:6817. [PubMed: 17072330]

11. Jost PJ, Ruland J. Blood. 2007; 109:2700. [PubMed: 17119127]

12. Escarcega RO, Fuentes-Alexandro S, Garcia-Carrasco M, Gatica A, Zamora A. Clin Oncology. 2007; 19:154.

13. Mizufune H, Nakamura M, Mitsudera H. Tetrahedron. 2006; 62:8539.

14. Boyd, MR. Status of the NCI preclinical antitumor drug discovery screen. In: De Vita, VT.; Hellman, S.; Rosenberg, SA., editors. Cancer: Principles and Practice of Oncology Updates. J.B. Lippincott; Philadelphia: 1989. p. 1

15. Monks A, Scudiero D, Skehan P, Shoemaker R, Paull K, Vistica D, Hose C, Langley J, Cronise P, Vaigro-Woiff A, Gray-Goodrich M, Campbell H, Mayo J, Boyd M. J Natl Cancer Inst. 1991; 83:757. [PubMed: 2041050]

16. Rubinstein LV, Shoemaker RH, Paull KD, Simon RM, Tosini S, Skehan P, Scudiero DA, Monks A, Boyd MR. J Natl Cancer Inst. 1990; 82:1113. [PubMed: 2359137]

17. Jain N, Yada D, Shaik TB, Vasantha G, Reddy PS, Kalivendi SV, Sreedhar B. ChemMedChem. 2011; 6:859. [PubMed: 21472861]

18. Hayden MS, Ghosh S. Cell. 2008; 132:344. [PubMed: 18267068]

19. Vichai V, Kirtikara K. Nature Protocols. 2006; 1:1112. 


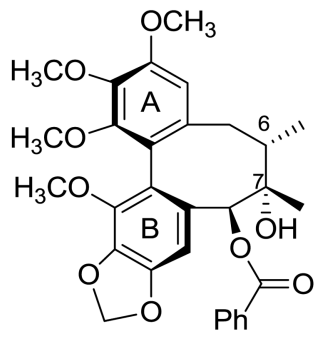

Gomisin G

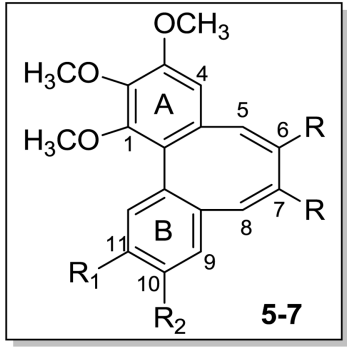

Lignan analogs:

Dibenzocyclooctatetraenes
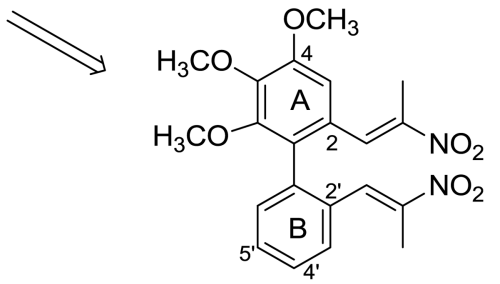

1 (lead)

$\mathrm{GI}_{50} \quad 0.12-0.51 \mu \mathrm{M}$

(A549, DU145, KB, KBvin)

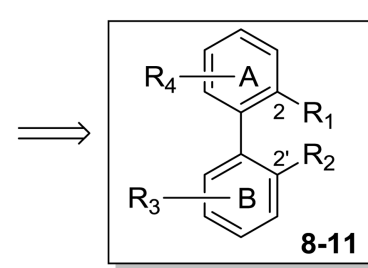

New unsymmetrical biphenyls

$\mathrm{R}_{3}, \mathrm{R}_{4}: \mathrm{OCH}_{3}, \mathrm{OCH}_{2} \mathrm{O}, \mathrm{H}$

Figure 1. Design strategy and new target compounds (5-11) 


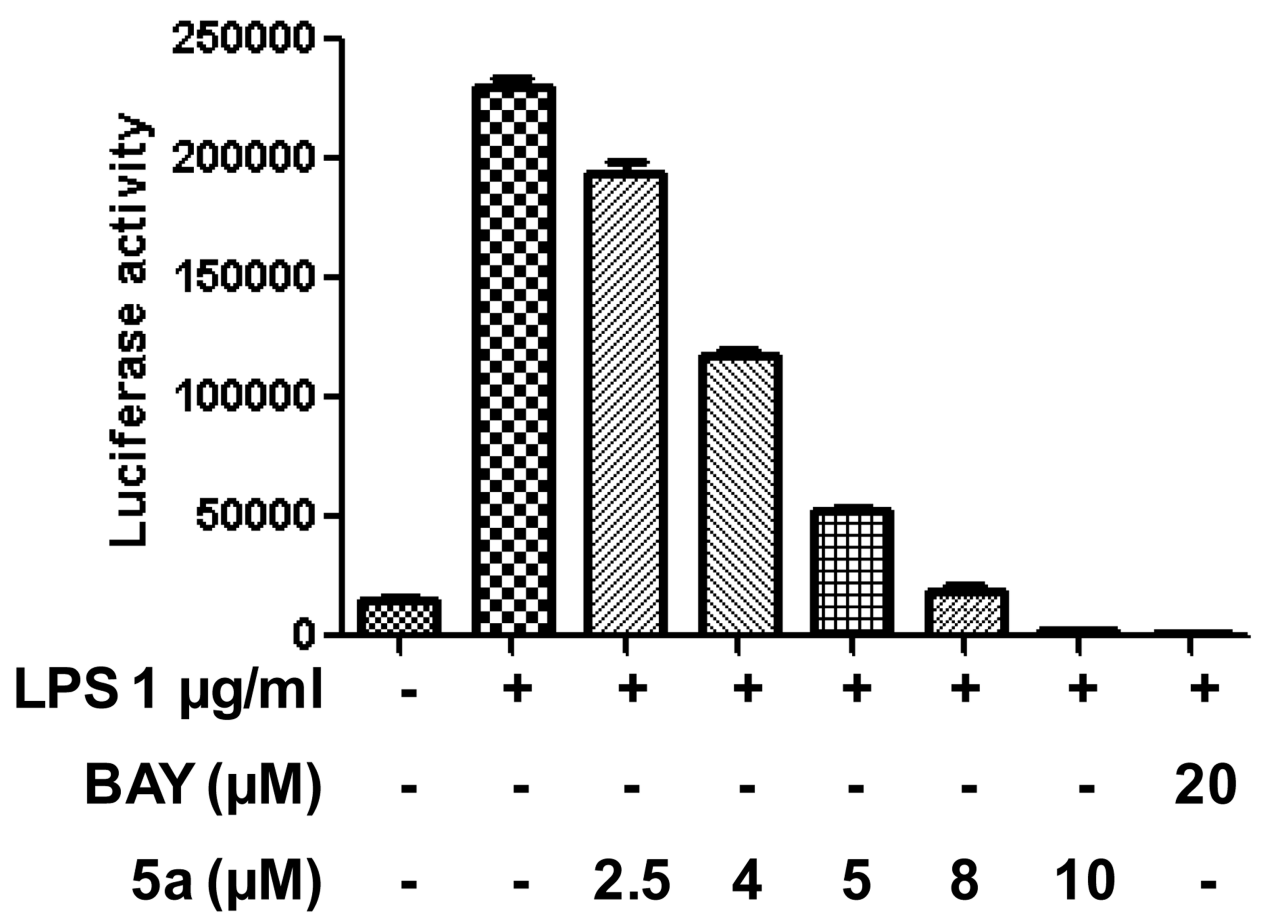

Figure 2.

Effect of 5a on LPS-induced NF- $\kappa$ B activation. RAW264.7 cells were pretreated with 5a at a dose of $2.5,4,5,8,10 \mu \mathrm{M}$ or BAY11-7082 $(20 \mu \mathrm{M})$ for $30 \mathrm{~min}$ before being stimulated with LPS $(1 \mu \mathrm{g} / \mathrm{mL})$ for $6 \mathrm{~h}$, and the luciferase activities were measured by NF- $\kappa \mathrm{B}$ luciferase reporter gene assays. 

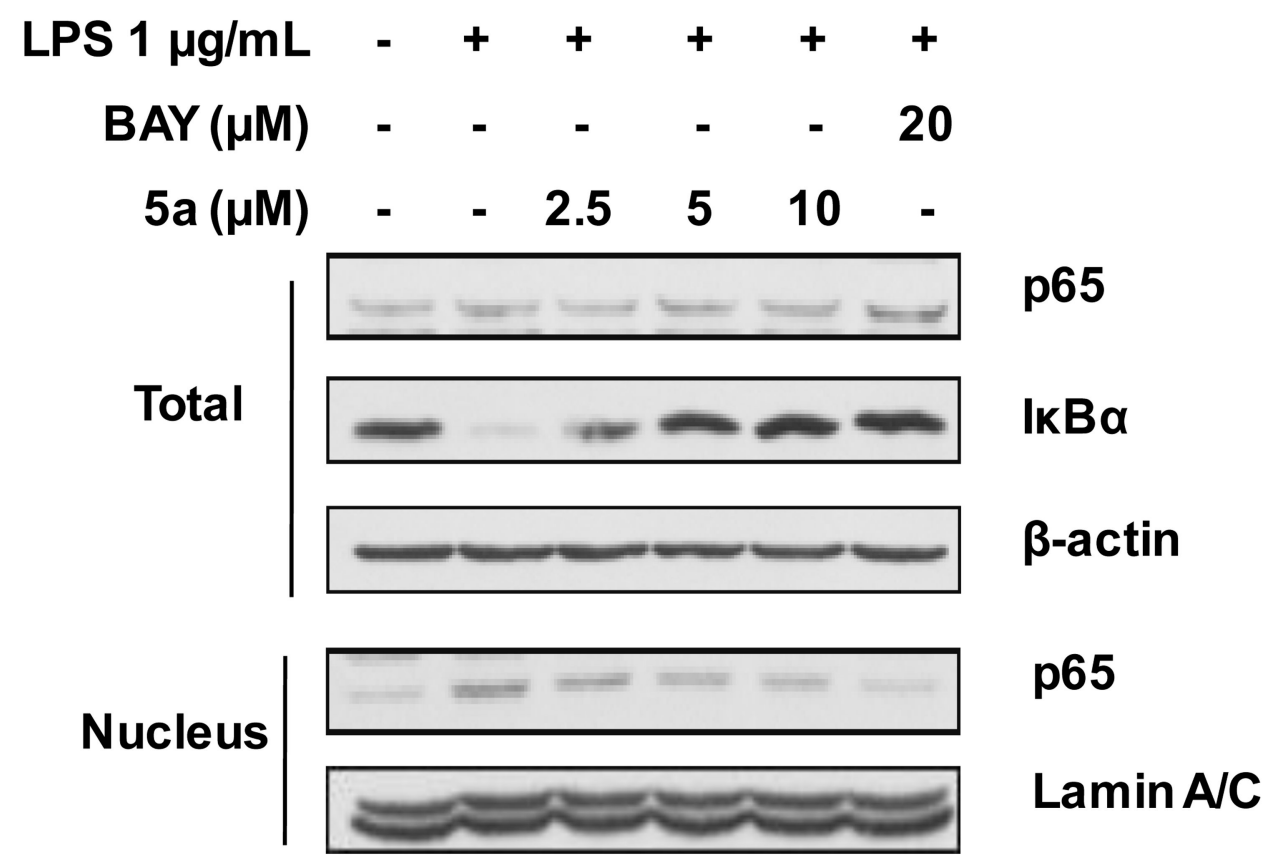

Figure 3.

Effect of 5a on degradation of I $\mathrm{B}$ B-a and translation of p65 in LPS-stimulated RAW264.7 cells. RAW264.7 cells were pretreated with 5a at a dose of 2.5, 5, $10 \mu \mathrm{M}$ or BAY11-7082 $(20 \mu \mathrm{M})$ for $30 \mathrm{~min}$, and stimulated by $1 \mu \mathrm{g} / \mathrm{mL}$ LPS for another $15 \mathrm{~min}$. The I $\mathrm{B}-\mathrm{a}$ in total cell protein and p65 in nuclear protein were detected by Western blot analysis. 


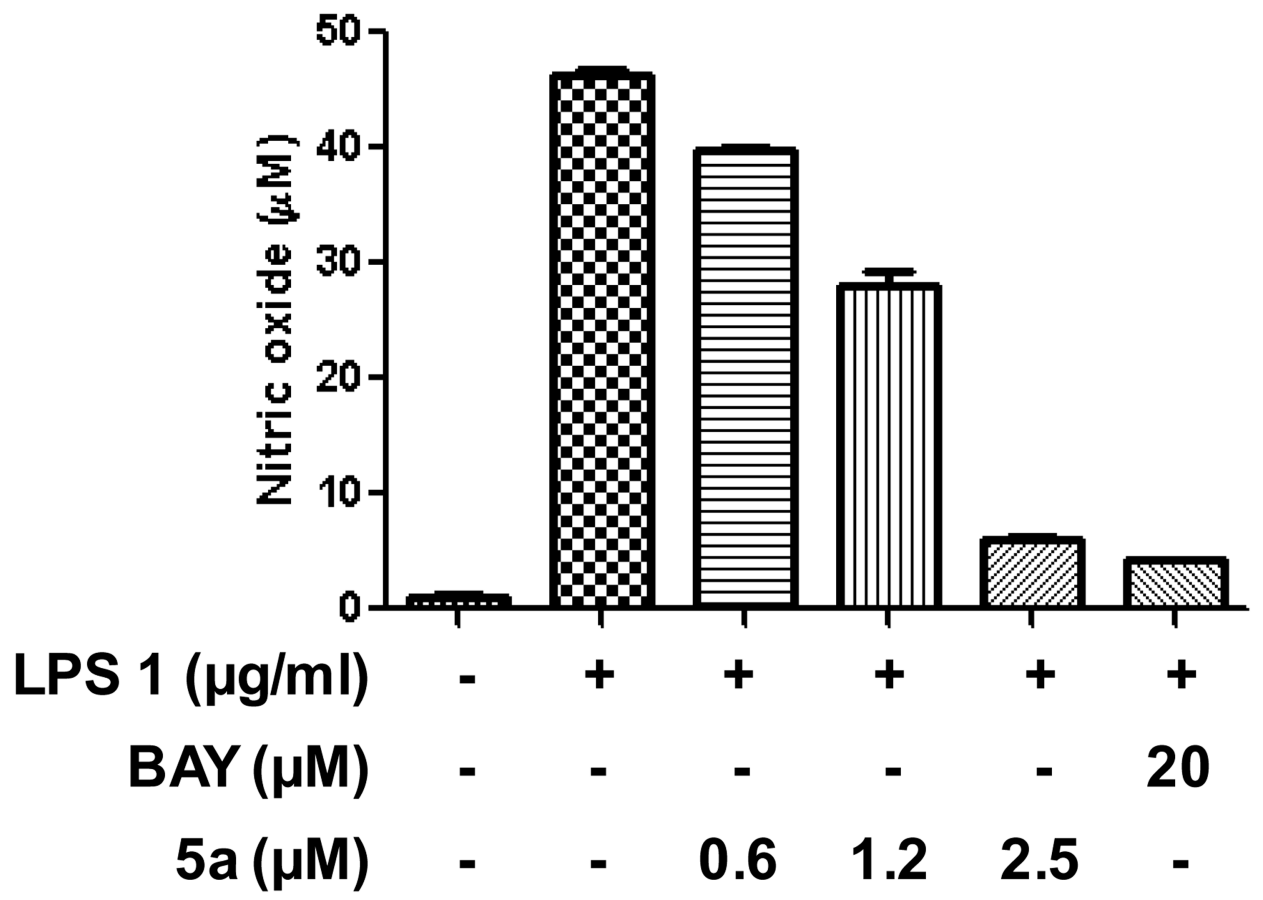

Figure 4.

Effect of 5a on NO production in LPS-induced RAW264.7 cells. After cells were pretreated with either 5a $(0.6,1.2$ and $2.5 \mu \mathrm{M})$ or BAY11-7082 $(20 \mu \mathrm{M})$ for $30 \mathrm{~min}$ and then simulated by LPS $(1 \mu \mathrm{g} / \mathrm{mL})$ for $18 \mathrm{~h}$, the production of NO in cell culture medium was analyzed by Griess assay. 


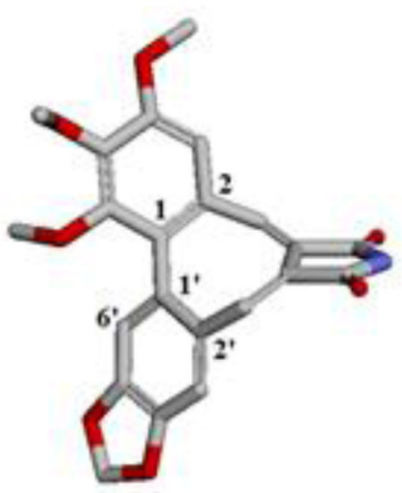

$5 a$

$129.8^{\circ}$

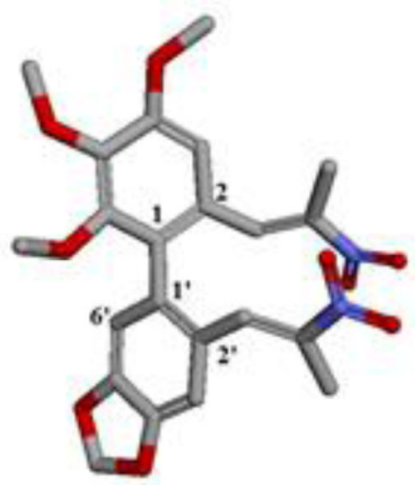

9a

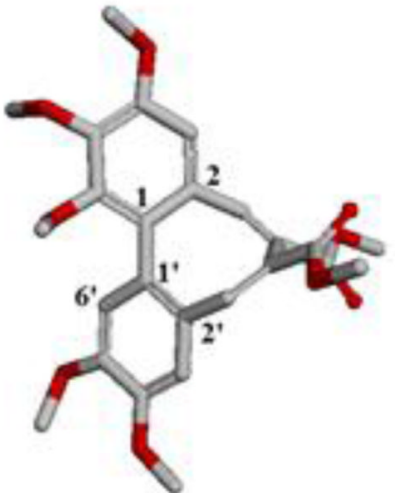

$6 b$

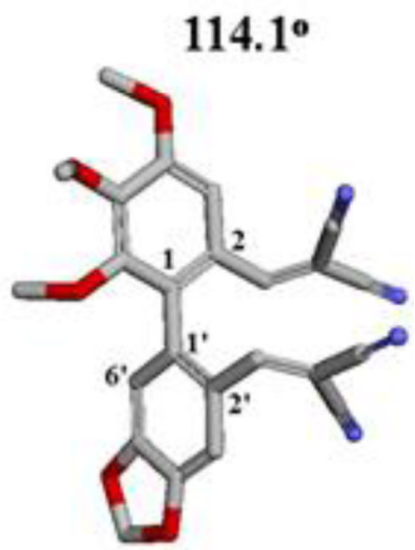

9c

Figure 5.

The low energy conformations of $\mathbf{5 a}, \mathbf{6 b}, 9 \mathbf{a}$, and $9 \mathbf{c}$ showing the torsional angles between two phenyl rings. The $\mathrm{C} 2-\mathrm{C} 1-\mathrm{C1}^{\prime}-\mathrm{C}^{\prime}$ torsional angle is defined as positive if, when viewed along the $\mathrm{C} 1-\mathrm{C}^{\prime}$ bond, atom $\mathrm{C} 2$ must be rotated counter-clockwise to eclipse atom $\mathrm{C}^{\prime}$. 
<smiles>COc1cc(C=O)c(Br)c(OC)c1OC</smiles><smiles>[R]c1cc(Br)c(C=O)cc1[R]</smiles>

a $\mathrm{R}_{1} \mathrm{R}_{2}=\mathrm{OCH}_{2} \mathrm{O}$

b $\mathrm{R}_{1}=\mathrm{R}_{2}=\mathrm{OCH}_{3}$

c $R_{1}=R_{2}=H$<smiles>[R]Cc1cc(C)c(-c2c(C)cc(OC)c(OC)c2OC)cc1[R2]</smiles><smiles>COc1ccco1</smiles><smiles>[R]c1cc2cc3c(=O)[nH]c(=O)c-3cc3cc(OC)c(OC)c(OC)c3c2cc1[R2]</smiles><smiles>COC(=O)COC(C)=O</smiles><smiles>[R]c1cc2c(cc1[R])=c1c([R])c(OC)c(OC)cc1=CC(C(C)=O)=C(C(=O)O[18OH])C=2</smiles>

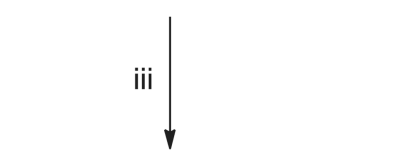<smiles></smiles>

Scheme 1. (i) Pd(dppf)Cl $\mathrm{Cl}_{2}, \mathrm{Cs}_{2} \mathrm{CO}_{3}$, 1,2-dimethoxyethane (DME), reflux, 8-12 h; (ii) (a) $\mathrm{Bu}_{3} \mathrm{P}$, THF, reflux, 8-12 h; (b) piperidine, HOAc, $100{ }^{\circ} \mathrm{C}, 4-6 \mathrm{~h}$; (iii) $10 \% \mathrm{NaOH}$ aq, THF, $50{ }^{\circ} \mathrm{C}, 1 \mathrm{~h}$; (iv) (a) $\mathrm{Bu}_{3} \mathrm{P}$, THF, MW, $10{ }^{\circ} \mathrm{C}, 2 \mathrm{~h}$; (b) piperidine, HOAc, benzene, reflux 

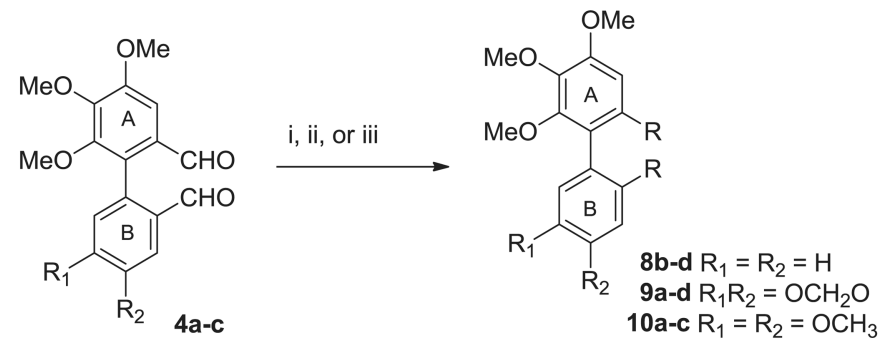

$\mathrm{R}=$

a $\mathrm{CH}=\mathrm{C}(\mathrm{Me}) \mathrm{NO}_{2}$

b $\mathrm{CH}=\mathrm{C}(\mathrm{CN}) \mathrm{CO}_{2} \mathrm{Et}$

c $\mathrm{CH}=\mathrm{C}(\mathrm{CN})_{2}$

d $\mathrm{CH}=\mathrm{CHNO}_{2}$

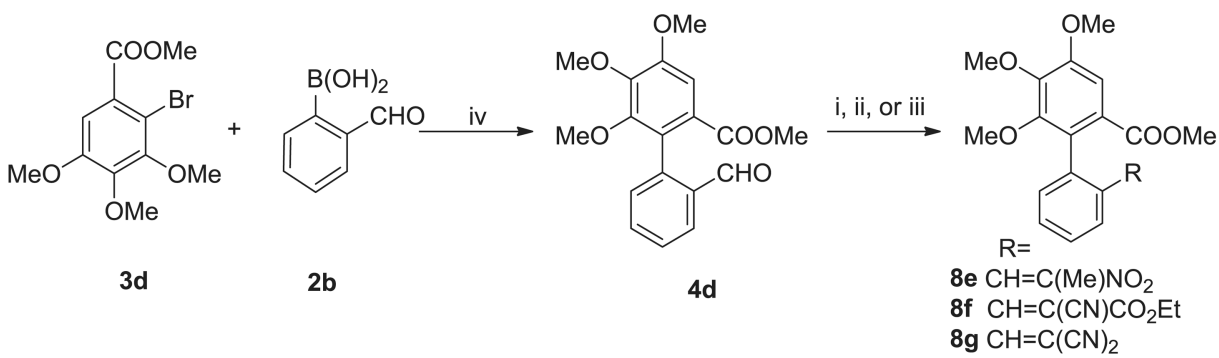<smiles>[R]c1cc(C=O)c(Br)c([R])c1CCC</smiles><smiles></smiles><smiles>[R]c1cc(C=O)c(-c2ccccc2C=O)c([R])c1[R]</smiles><smiles>[R]c1cc(/C=C(/N=C(C)/C=C(\C)[N+](=O)[O-])[N+](=O)[O-])c(-c2ccccc2)c([R])c1[R]</smiles>

3e $\mathrm{R}_{1}=\mathrm{OMe}, \mathrm{R}_{2} \mathrm{R}_{3}=\mathrm{OCH}_{2} \mathrm{O}$ 3f $\mathrm{R}_{1} \mathrm{R}_{2}=\mathrm{OCH}_{2} \mathrm{O}, \mathrm{R}_{3}=\mathrm{OMe}$

$4 \mathrm{e}, \mathrm{f}$

$11 \mathrm{a}, \mathrm{R}_{1}=\mathrm{OMe}, \mathrm{R}_{2} \mathrm{R}_{3}=\mathrm{OCH}_{2} \mathrm{O}$ 11b, $\mathrm{R}_{1} \mathrm{R}_{2}=\mathrm{OCH}_{2} \mathrm{O}, \mathrm{R}_{3}=\mathrm{OMe}$

Scheme 2.

(i) $\mathrm{CH}_{3} \mathrm{CH}_{2} \mathrm{NO}_{2}$ or $\mathrm{CH} 3 \mathrm{NO} 2, \mathrm{HOAc} / n-\mathrm{BuNH}_{2}, 95^{\circ} \mathrm{C}, 72 \mathrm{~h}$; (ii) $\mathrm{CH}_{2}(\mathrm{CN}) \mathrm{COOEt}, \mathrm{PPh}_{3} /$ HOAc, $110{ }^{\circ} \mathrm{C}, 8$ h, 63 69\%; (iii) $\mathrm{CH}_{2}(\mathrm{CN})_{2}$, EtOH, r.t, 6-24 h, 49 70\%; (iv)

$\mathrm{Pd}(\mathrm{dppf}) \mathrm{Cl}_{2}, \mathrm{Cs}_{2} \mathrm{CO}_{3}, 1,2$-dimethoxyethane (DME), reflux, 8-12 h. 


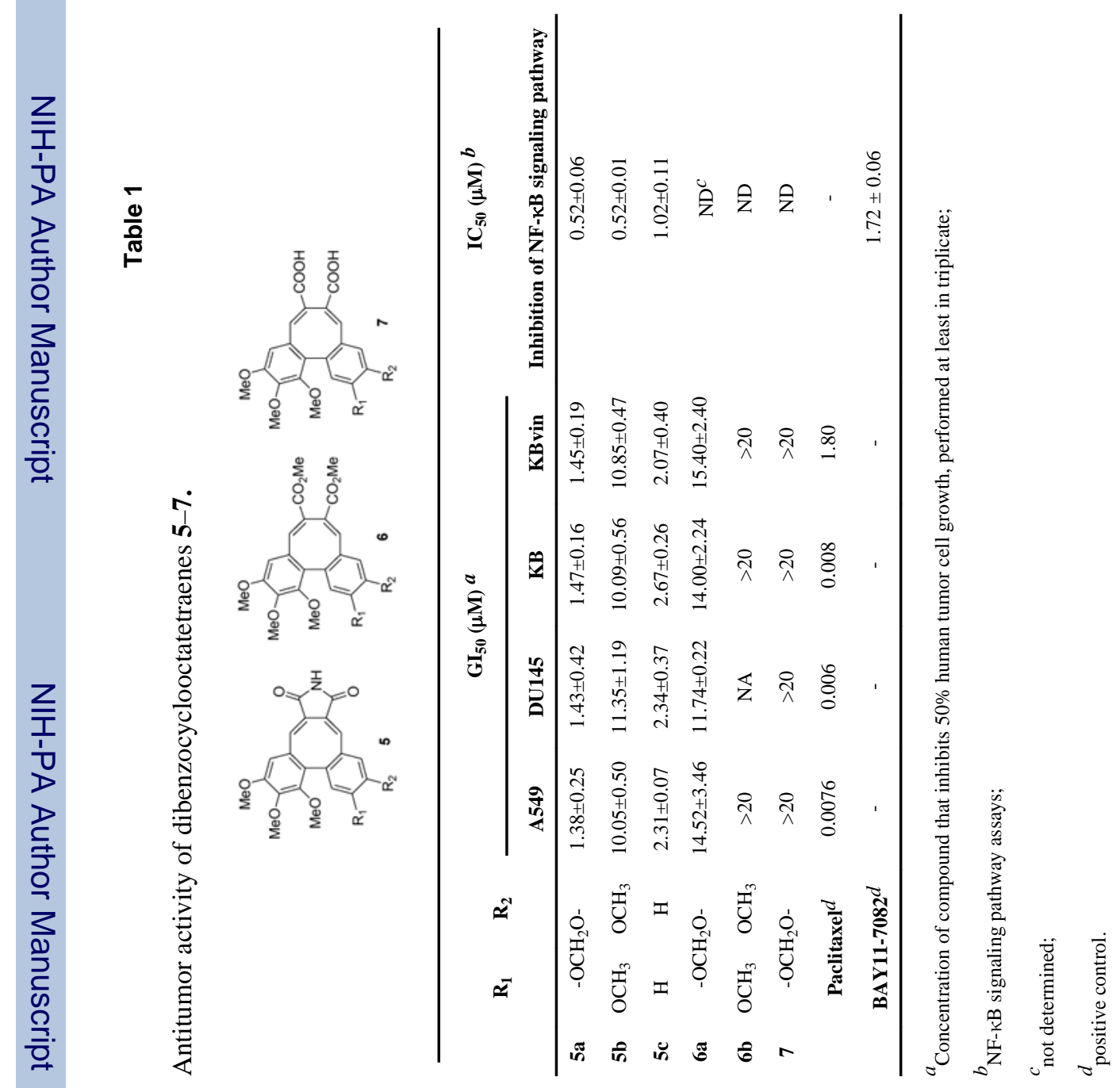




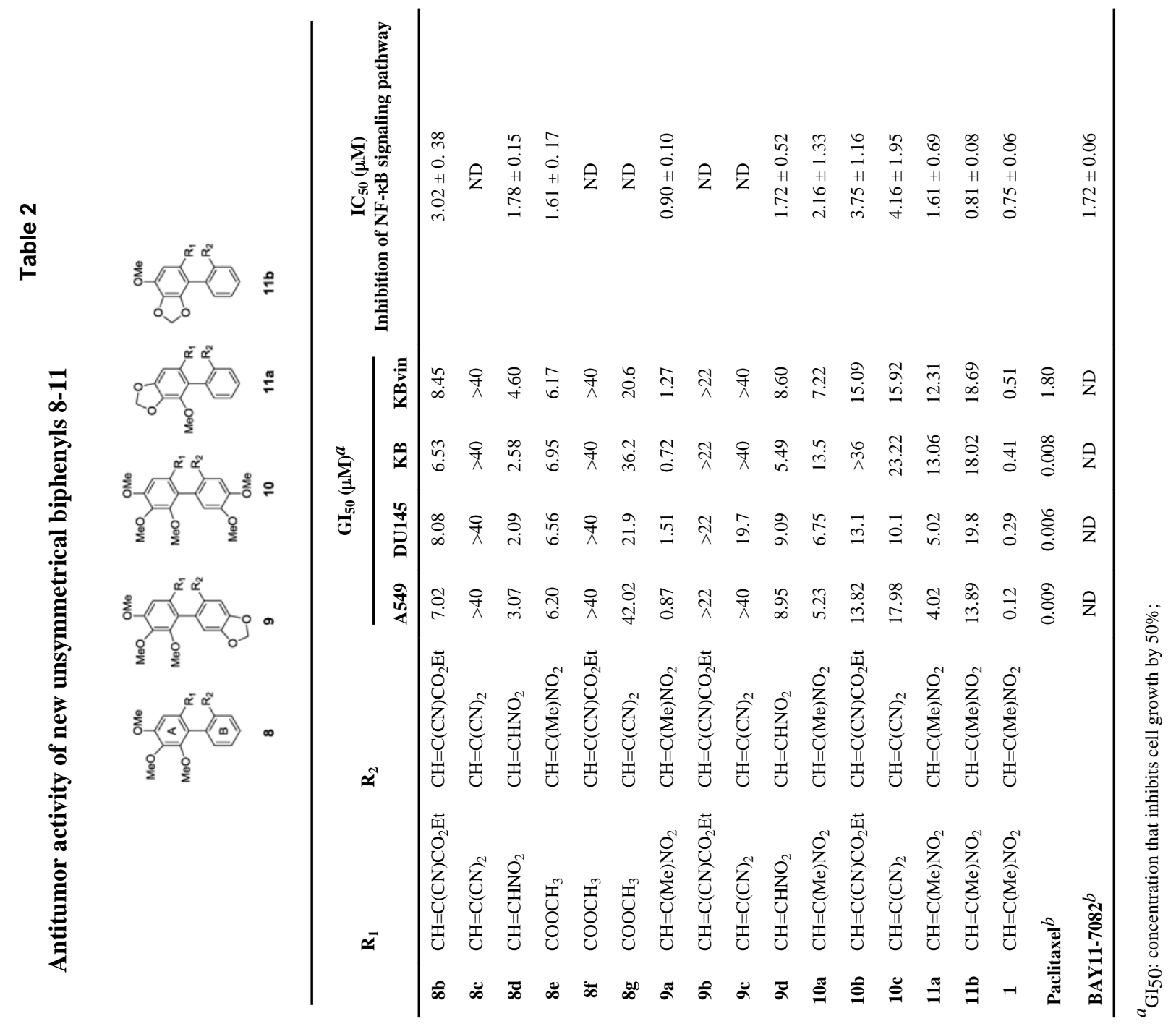


